استفاده از نخرش تحليل مؤلفهاى اصلى براى وزندهى ويزّى هاى آمارى، اقليمى و جغر افيايى حداكثر بارندگى FF ساعته و تحليل مكانى خوشهبندى (مطالعه موردى: حوضه درياجه اروميه)

\author{
زهره دهقان "، سيد سعيد اسلاميان' و رضا مدرس r

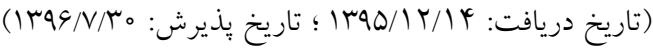

\begin{abstract}
جكيده

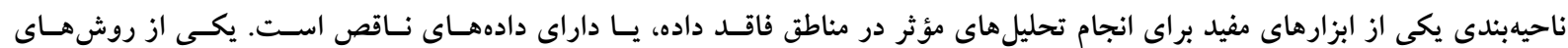

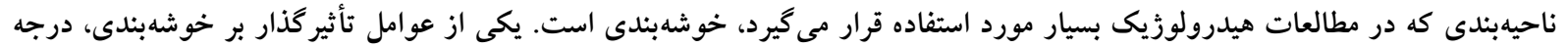

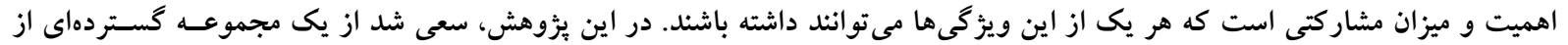

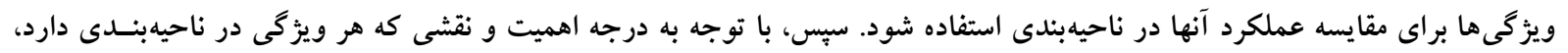

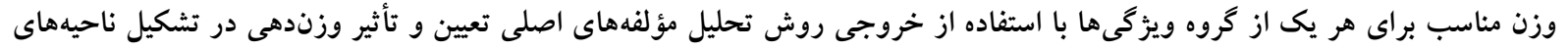

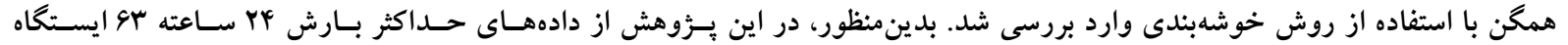

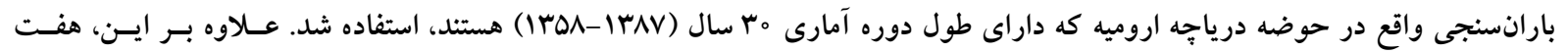

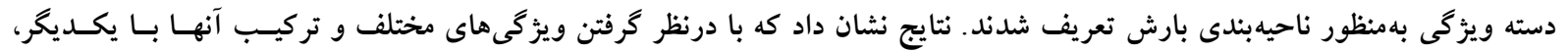

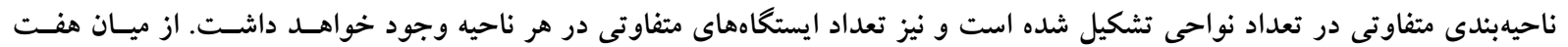

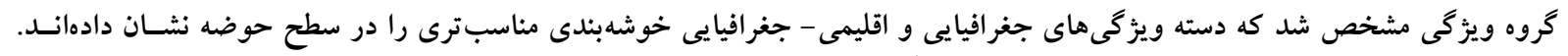

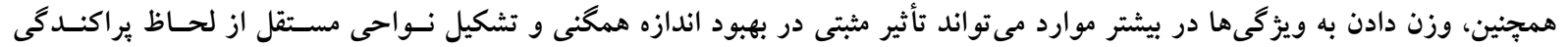

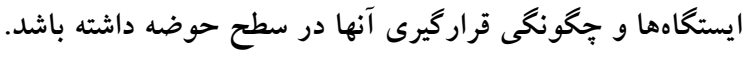

وازههاى كليدى: تحليل مؤلفههاى اصلى، حوضه درياجه اروميه، روش خوشهبندى وارد، وزندهى ويزگىها

ا. كروه مهندسى آب، دانشكده كثاورزى، دانشگاه صنعتى اصفهان

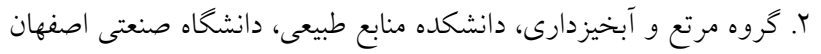

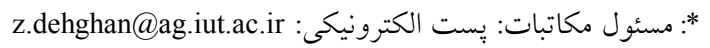


دادههاى بارش ماهانه از سال 1901 تـا 1999 يرداخـت. وى از

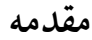

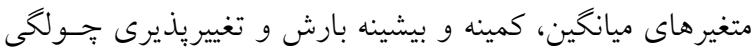

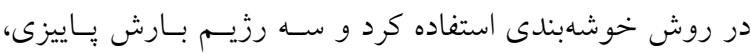

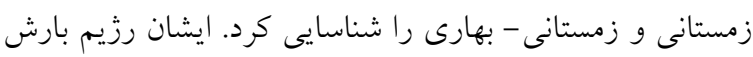

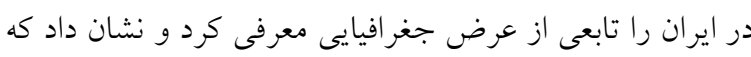

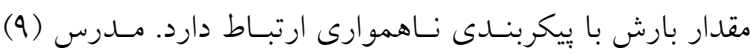

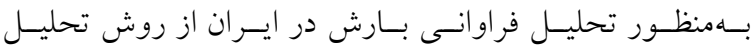

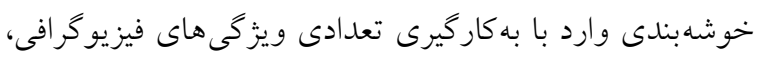

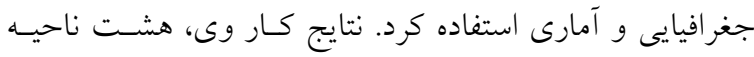

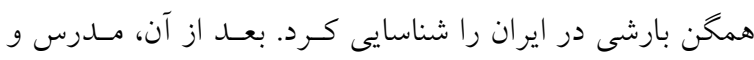

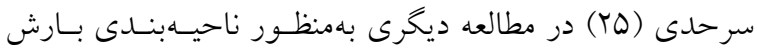

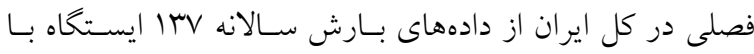

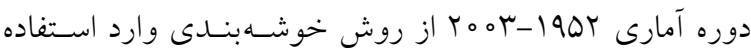

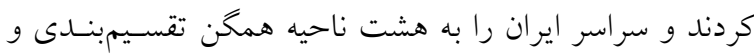
نتايج تحقيق مدرس (9) را تأييد كردند.

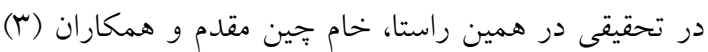
به منظور يهنهبندى حداكثر بارشهـاى روزانـه از روش تحليـل

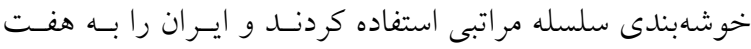

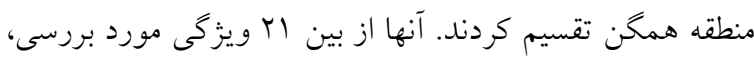

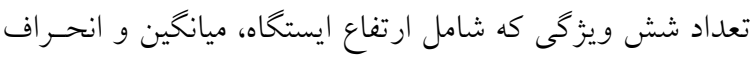

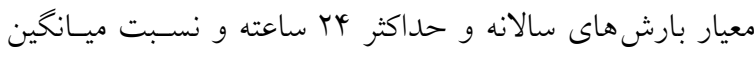

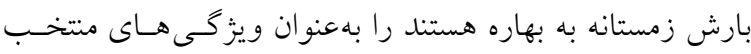
براى انجام ناحيهبندى انتخاب كردند. شيروانى و نظام السـادات

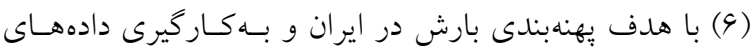

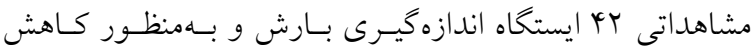
متغيرهاى ورودىى، از روش تحليل مؤلفـهــاى اصسلى استفاده

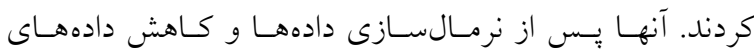
مشاهداتى با استفاده از روش خوشهبندى وارد، كشور ايـران را

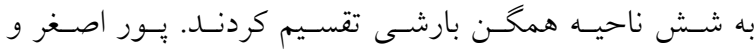

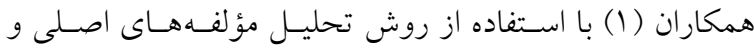
به كاركيرى روش خوشهبندى، بارش نواحى جنوبى ايسران را بـا بـا

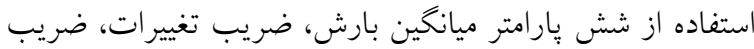

يكى از مشكلات هيدرولوزيستها در انجام تحليل هاى آمارى، نبود دادههايى با طول دوره آمارى مناسب يا عدم وجود داده در مناطق مورد مطالعه است. سوابق اطلاعات هيدرولوزيك (بارش و سيلاب) عمدتاً كوتاه بوده و يادر دسـترس نيسـت. بنـابراين،

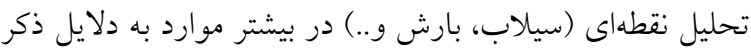

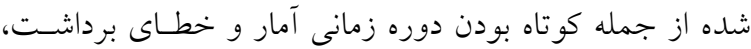
اطلاعات موجود قادر به ياسخگكويى به يِشبينىهاى دراز مدت

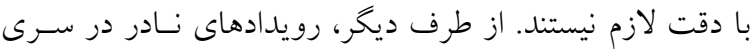
زمانى ثبت شده نقطهاى بهدليل محدوديت دوره زمـانى، نمونـهـ آمارى را از جامعه مجزا نشان مىدهد و انجام تحليل در منطقـهـ

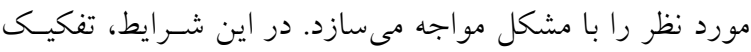

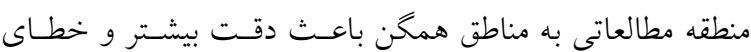

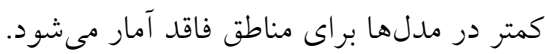
بسته به هدفى كه از ناحيهاى كردن منطقه وجود دارد و نيـز كيفيت و كميت دادهاى قابل دسترس روش هاى مختلفى وجود

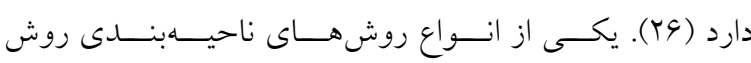

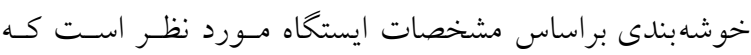
توسط هاسكينخ و و الـيس در سـال 1997 ارائسه شـــ (19). الكوريتمهاى زيادى براى تحليل خوشهبندى ييشنهاد شده اسـت

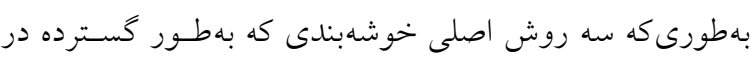
مطالعات مختلف استفاده شدهاند عبارتنداند: خوشهبندى سلسله مراتبى، خوشهبندى غيرسلسـله مراتبى و خوشـهبنــى فـازى.

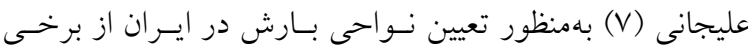

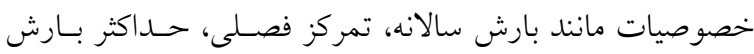

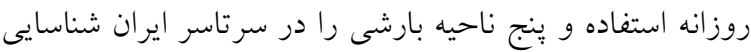
كرد. جهانبخش و ذوالفقارى (Y) نيز با استفاده از روش تحليل مؤلفههاى اصلى و بهكار كيرى دادههاى بارش روزانه ب ايستخاه سينويتيك در غرب ايران، براى هشت مــاه مرطسوب (اكتبـر تـا

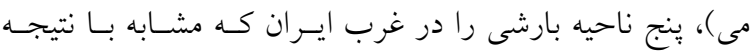
عليجانى (V) است، مشخص كردند. مسعوديان (10) بـهمنظور تعيين مناطق بارشى در ايــران بـه تهيـه نقشـهـ رقـومى ايـران از 
مقادير آمارى محاسبه شـده از سـرىهـاى زمـانى در دسـترس در

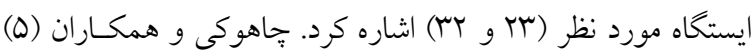

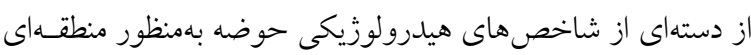

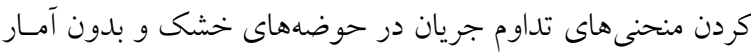

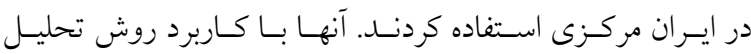

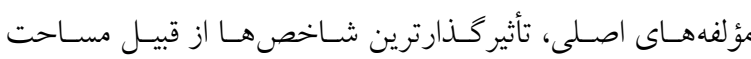
حوضه، طول آبراهه، شيب آبراهه اصلى و متوسط بارندكى سـالانه

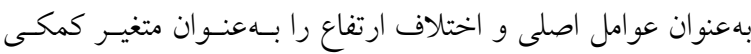
بهمنظور بيشبينى دبى در منـاطق مـورد نظـر انتخـاب كردنـــ در

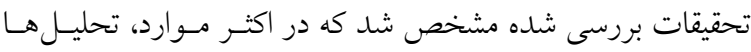
براساس تعداد محدودى از ويزگكىهـا (اقليمسى، جغرافيسايى و ...)

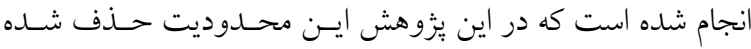

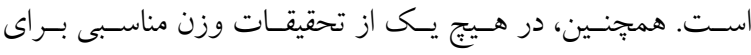

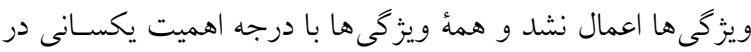

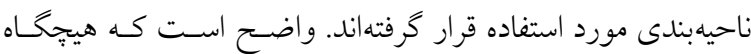

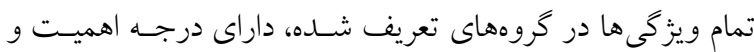

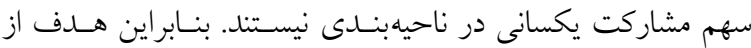
يززوهش حاضر، ناحيهاى كردن حداكثر بـارش با سـاعته حوضـه

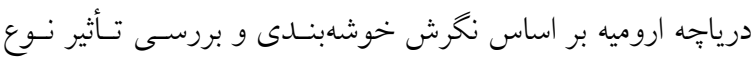

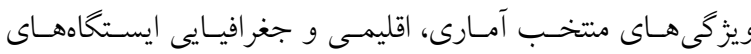

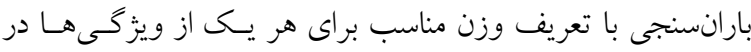

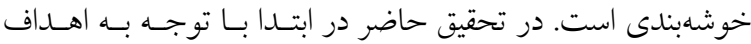

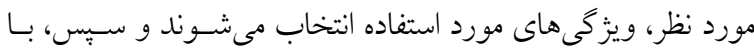
استفاده از خروجى مدل تحليل مؤلفههاى اصلى، براى هـر يـــ از

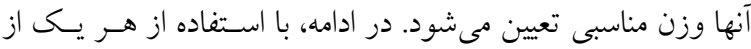

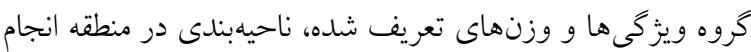
مىشود و نتايج خوشهبندى مورد بررسى قرار خواهند كرفت.

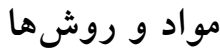

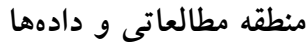
در اين يزوهش بهمنظور دستيابى به اهداف مورد نظـ، حوضسه

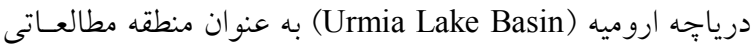

كشيدگى، ضريب جولكَى، حداقل و حداكثر بارش به بنج ناحيه

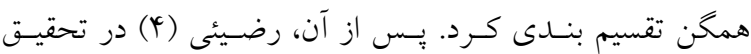

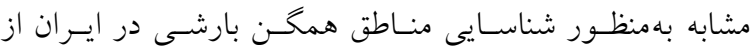

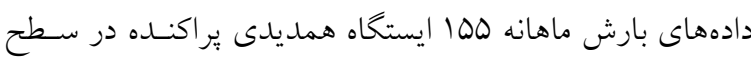

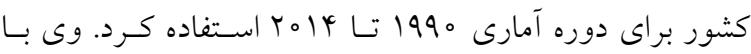

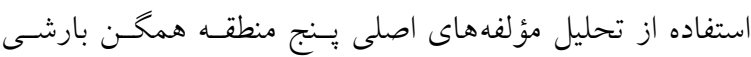

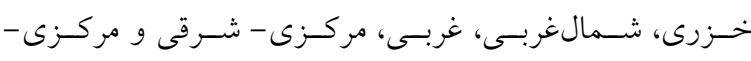

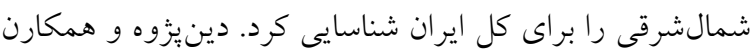

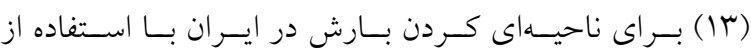
تكنيك هاى خوشهبندى از دادهاى بارش VV ايستخاه استفاده

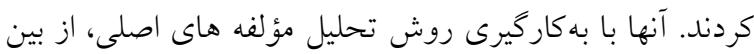

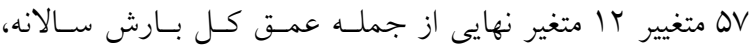

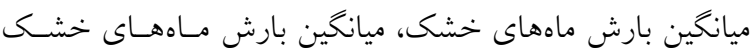

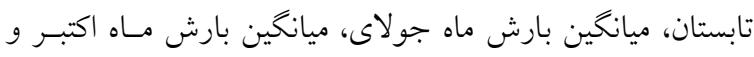

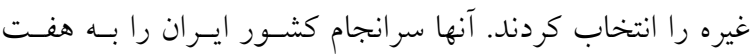

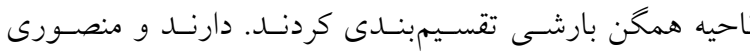

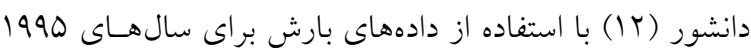

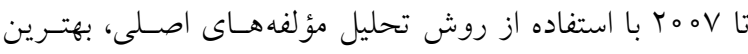

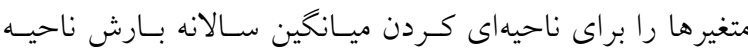

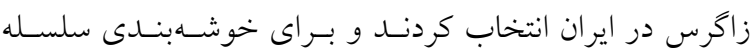

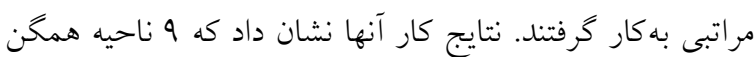
بارش فصلى در ايران وجود دارد.

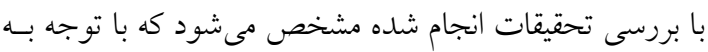

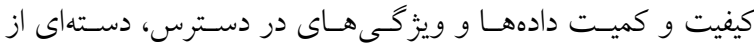
ويزگى ها بهمنظور انجام ناحيهبندى انتخاب مىشوند. از جمله ديكر

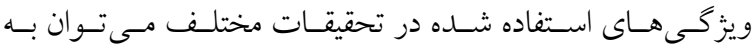
ويزگكىهاى فيزيكى حوضه مانند مساحت زهكشى، شيب ميـانخين

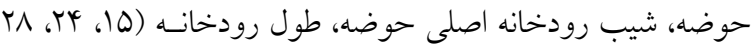

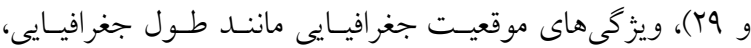
عرض جغرافيايى و طول جغرافيايى از مركر حوضسه (مب)، عوامـل

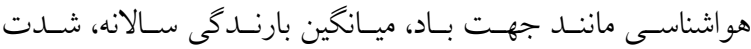

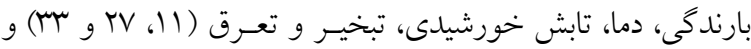




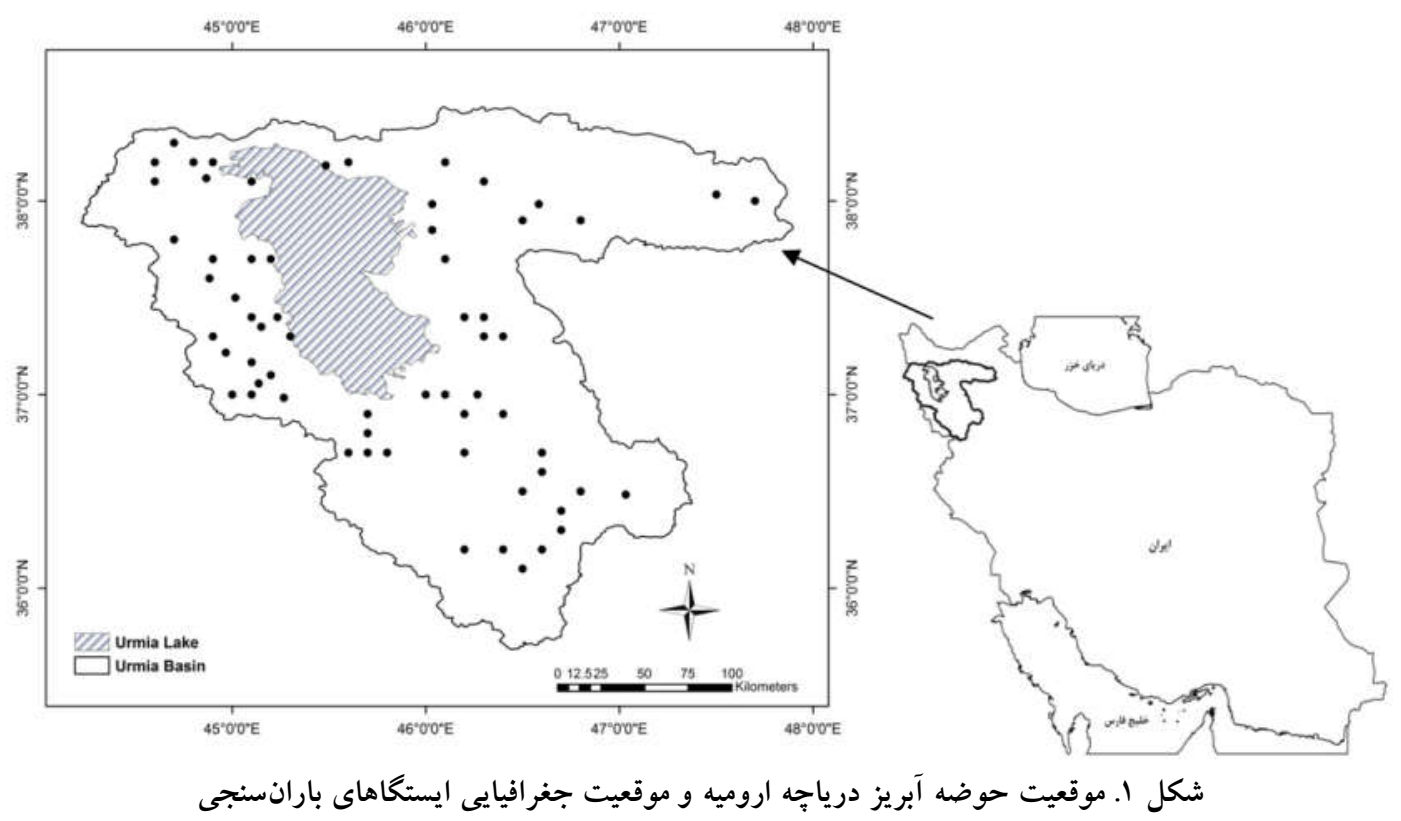

اروميه از خروه كستردهاى از اطلاعـات آمـارى (Statistical)،

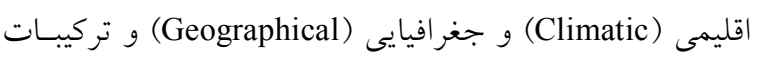
مناسب آنها در بزوهش حاضر استفاده شد. در ادامه با استفاده

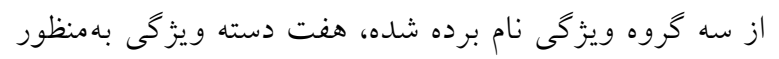

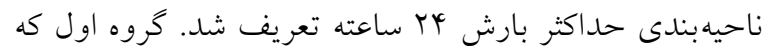

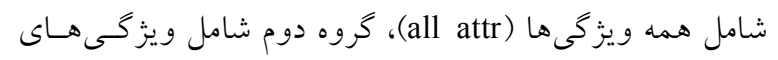

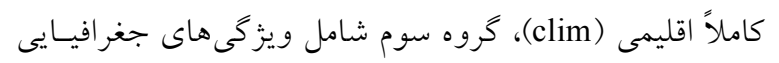

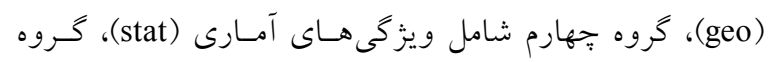

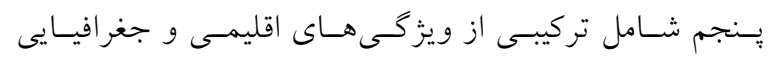

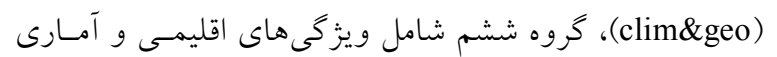

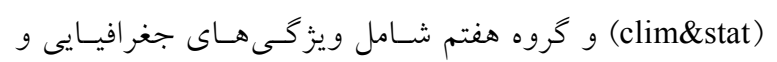

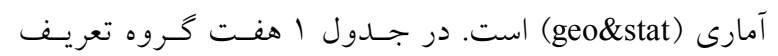

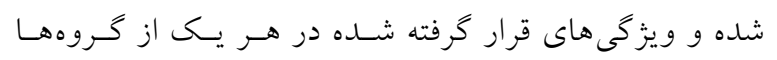
مشخص شده است.

\section{فاصله اقليدسى (Euclidean distance)}

در فضاى متريك، مشابهت اغلب بر اساس معيار فاصله تعريف (فيل

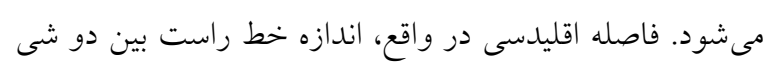

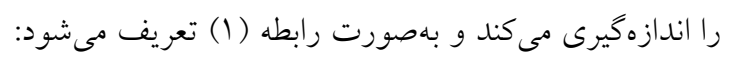

درنظر گرفته شد. حوضه آبريز درياجه اروميه با مساحت حدود

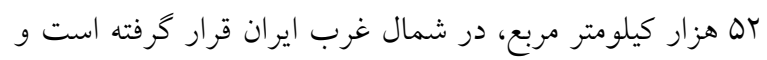

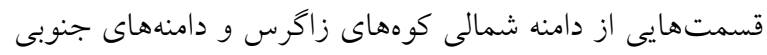

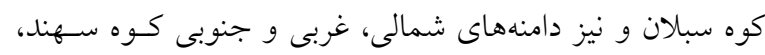

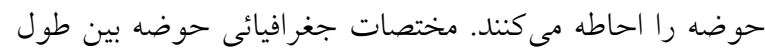

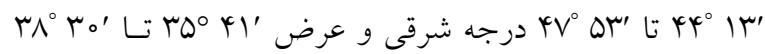

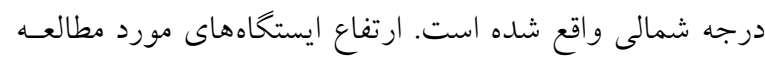

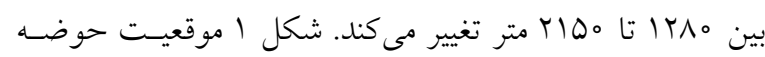

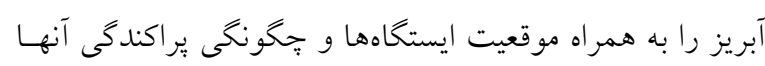

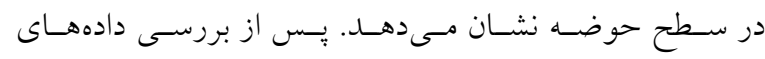

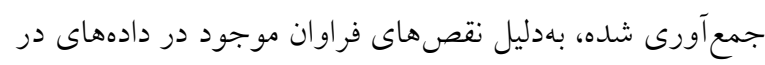

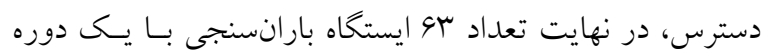

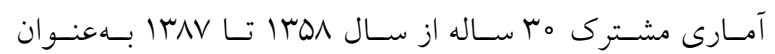
ايستخاههاى منتخب مورد استفاده قرار كرفتند.

\section{انتخاب ويزّى ها}

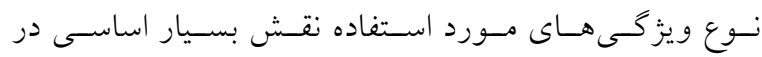

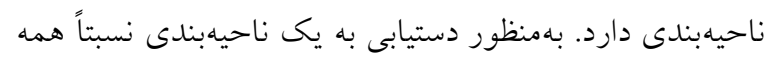

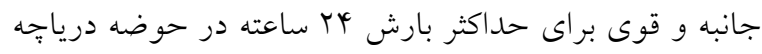




\begin{tabular}{|c|c|c|c|c|c|c|c|}
\hline \multicolumn{8}{|c|}{ جدول ا. مشخصات هفت گروه ويزّى تعريف شده } \\
\hline $\begin{array}{c}\text { جغر افيايى - آمارى } \\
\text { (stat\&geo) }\end{array}$ & $\begin{array}{l}\text { اقليمى- آمارى } \\
\text { (clim\&stat) }\end{array}$ & $\begin{array}{l}\text { اقليمى - جغر افيايى } \\
\text { (clim\&geo) }\end{array}$ & $\begin{array}{l}\text { آمارى } \\
\text { (stat) }\end{array}$ & $\begin{array}{c}\text { جغرافيايى } \\
\text { (geo) }\end{array}$ & $\begin{array}{l}\text { اقليمى } \\
\text { (clim) }\end{array}$ & $\begin{array}{c}\text { اقليمى - جغر افيايى - آمارى } \\
\text { (all attr) }\end{array}$ & 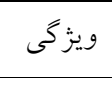 \\
\hline$\sqrt{2}$ & & $\sqrt{ }$ & & $\sqrt{ }$ & & $\sqrt{ }$ & $\mathrm{y}$ \\
\hline$\sqrt{ }$ & & $\sqrt{ }$ & & $\sqrt{ }$ & & $\sqrt{ }$ & $\mathrm{x}$ \\
\hline$\sqrt{ }$ & & $\sqrt{ }$ & & $\sqrt{ }$ & & $\sqrt{ }$ & $\mathrm{h}$ \\
\hline$\sqrt{ }$ & & $\sqrt{ }$ & & $\sqrt{ }$ & & $\sqrt{ }$ & $\mathrm{d}$ \\
\hline$\sqrt{ }$ & $\sqrt{ }$ & & $\sqrt{ }$ & & & $\sqrt{ }$ & $\mathrm{Sd}$ \\
\hline$\sqrt{ }$ & $\sqrt{ }$ & & $\sqrt{ }$ & & & $\sqrt{ }$ & $\mathrm{L}_{\mathrm{CV}}$ \\
\hline$\sqrt{ }$ & $\sqrt{ }$ & & $\sqrt{ }$ & & & $\sqrt{ }$ & LCS \\
\hline$\sqrt{ }$ & $\sqrt{ }$ & & $\sqrt{ }$ & & & $\sqrt{ }$ & $\mathrm{L}_{\mathrm{CK}}$ \\
\hline$\sqrt{ }$ & $\sqrt{ }$ & & $\sqrt{ }$ & & & $\sqrt{ }$ & $\mathrm{LCv} / \mathrm{LCS}$ \\
\hline$\sqrt{ }$ & $\sqrt{ }$ & & $\sqrt{ }$ & & & $\sqrt{ }$ & $\mathrm{LCV}_{\mathrm{CV}} / \mathrm{LCK}$ \\
\hline$\sqrt{ }$ & $\sqrt{ }$ & & $\sqrt{ }$ & & & $\sqrt{ }$ & MR25th \\
\hline$\sqrt{ }$ & $\sqrt{ }$ & & $\sqrt{ }$ & & & $\sqrt{ }$ & $\mathrm{MR} 75$ th \\
\hline & $\sqrt{ }$ & $\sqrt{ }$ & & & $\sqrt{ }$ & $\sqrt{ }$ & MAR \\
\hline & $\sqrt{ }$ & $\sqrt{ }$ & & & $\sqrt{ }$ & & $\mathrm{Rs} / \mathrm{Rw}$ \\
\hline & $\sqrt{ }$ & $\sqrt{ }$ & & & $\sqrt{ }$ & $\sqrt{ }$ & $\mathrm{Dd} / \mathrm{Dw}$ \\
\hline
\end{tabular}

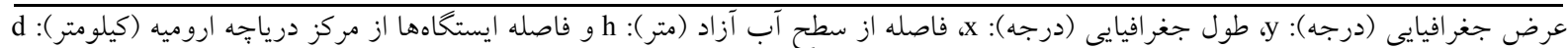

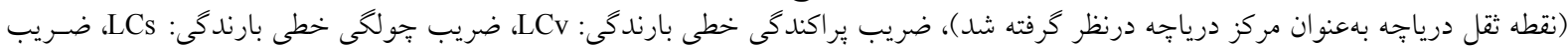

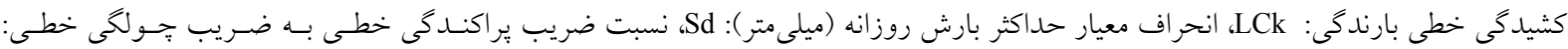

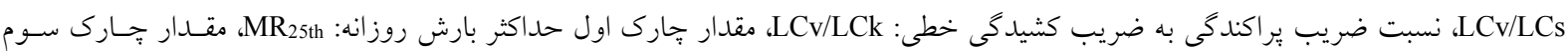

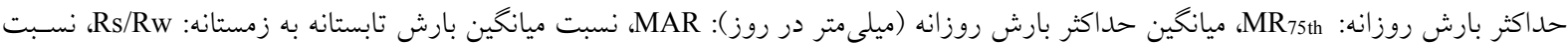

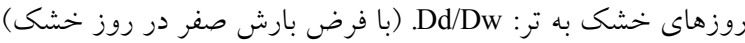

فاصله اقليدسى بيشترين كاربرد را در اندازهيرى ميـزان تشـابه

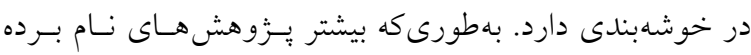
شده در بالا، از فاصله اقليدسى براى اندازهيـــى ميـزان تشـابه

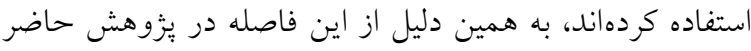

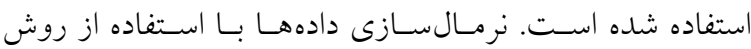

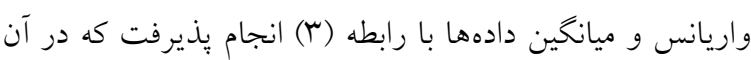
ميانخين و $\mathrm{X}^{*}=\frac{\mathrm{X}-\overline{\mathrm{X}}}{\sigma_{\mathrm{X}}}$

روش تحليل مؤلفههاى اصلى (Principal Component Analysis)

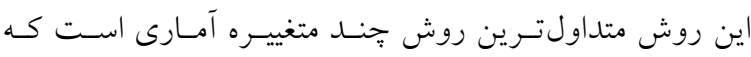

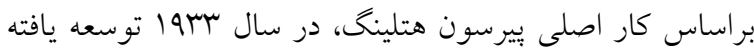
است. در اين روش، تحليل مؤلفههاى اصسلى نـوعى از تحليـل

$$
d_{i j}=\left[\sum_{m=1}^{M}\left(X_{m}^{i}-Y_{m}^{j}\right)^{r}\right]^{\frac{1}{n}}
$$

فاصله اقليدسى وزنداده شده نيز بهصورت رابطـهـ (r) تعريـف آلـ

$$
d_{i j}=\left[\sum_{m=1}^{M} W_{m}\left(X_{m}^{i}-Y_{m}^{j}\right)^{r}\right]^{\frac{1}{n}}
$$

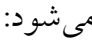

كسه در ايـن روابـط، dij فاصـله اقليدسى وزن داده شـــه بــين

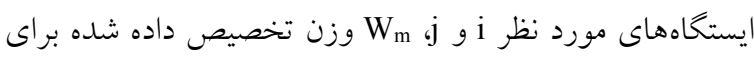

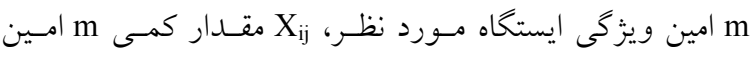

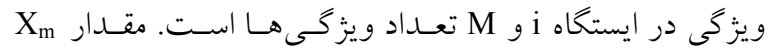

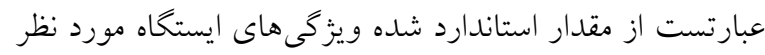

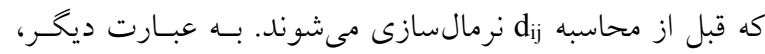

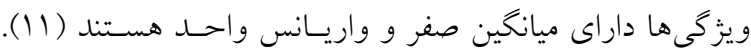


استفاده مى شود و در هر كام هر دو خوشه با حداقل فاصله با

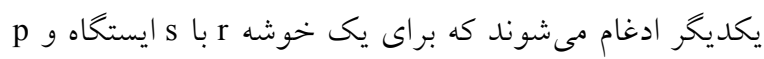

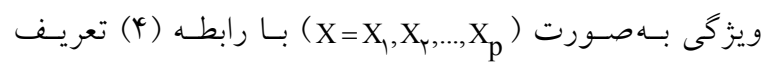

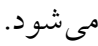

$\mathrm{ESS}_{\mathrm{r}}=\sum_{\mathrm{j}=1}^{\mathrm{S}}\left(\mathrm{X}_{\mathrm{j}}-\overline{\mathrm{X}_{\mathrm{r}}}\right)^{\prime}\left(\mathrm{X}_{\mathrm{j}}-\overline{\mathrm{X}_{\mathrm{r}}}\right)$

كه طبق اين رابطـه، شـامل بـردارى از

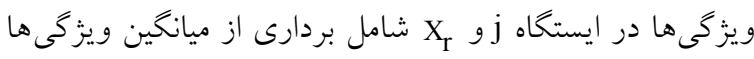

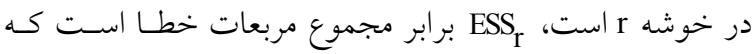

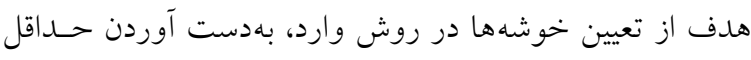

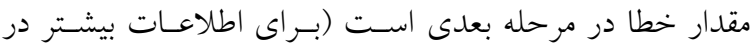

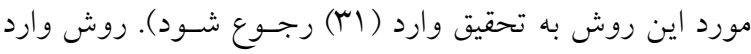
نسبت به ساير روشها نتايج بهترى ارائه كرده است، بـه همسين

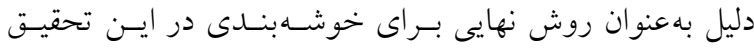

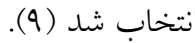

\section{آزمون ناهمخنى منطقهاى}

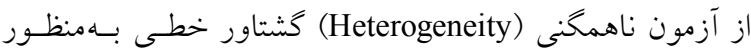

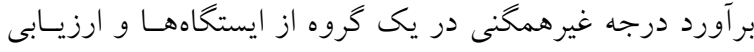

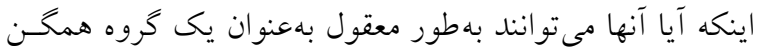
قرار گيرند يا نه، استفاده شده است. معيار غيرهمخنى، تغييـرات

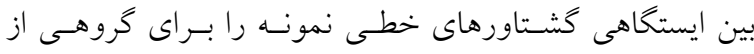
ايستخاهها با مقدار مورد انتظار براى يكى ناحيه همخـن مقايسـه

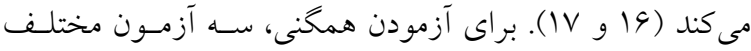
وجود دارد: ا- آزمون بر بِايه معيـار ؛ــراكنش خطى (L-CV)؛

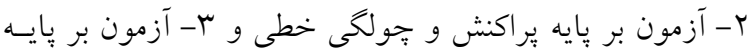

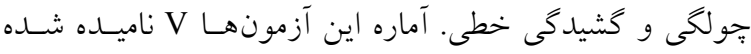
است و هاسكينگ و واليس (IV) مشاهده كردند كه آمـارههـاى بر اساس معيارهاى $\mathrm{H}_{r} \mathrm{H}_{r} \mathrm{H}_{r}$

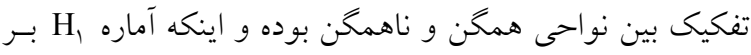
اساس معيار VI توان خيلى بهترى براى تفكيك دارد. بنسابر اين،

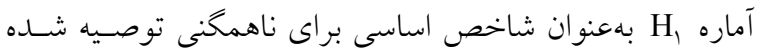

آمارى است كه تعداد كمترى از عوامل را به نام مؤلفههاى اصلى

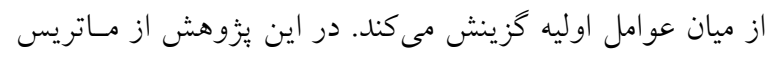

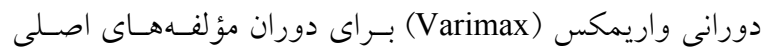

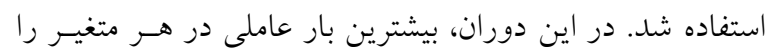

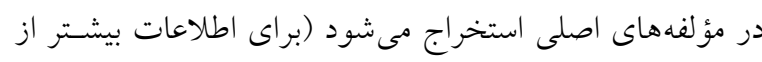

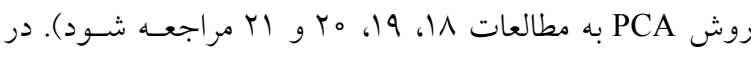
تحقيق حاضر نيز، از روش تحليل مؤلفههاى اصلى بهمنظور بيدا

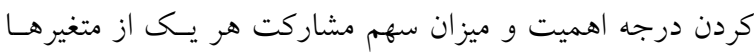

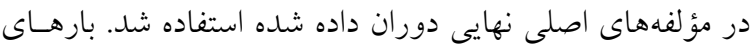

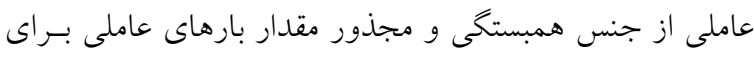

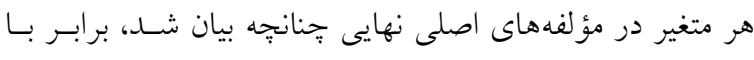

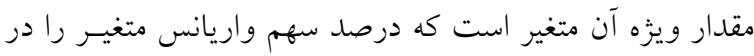

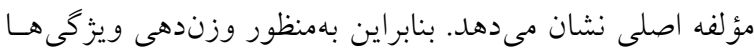

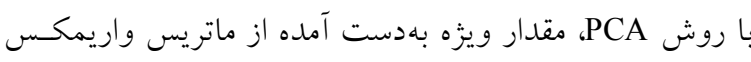

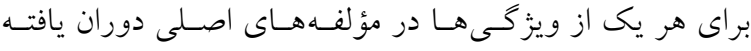
و بهصـورت مقــادير حداكثر و متوسطى از بارهاى عاملى (از جنس همبستخى) مورد

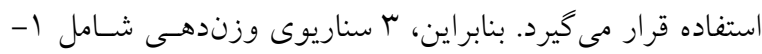

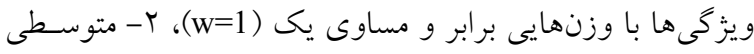
از مقادير ويزهه هر متغير در مؤلفـهــاى نهايى (w=PCA

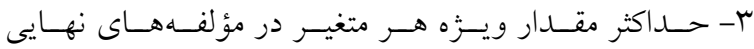
تعريف شدند. (w=PCA max $\left._{\text {max }}\right)$

خوشهبندى وارد (Ward)

روش وارد از جمله روشهاى خوشهبندى است كه هــف آن يافتن خوشه هاى كروى و متراكم است. روش وارد اغلـب در تحليل فروانى براى تشريح همخنى خوشهها مورد استفاده قرار

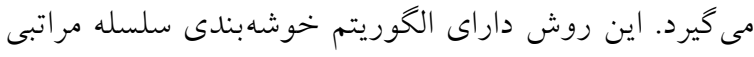

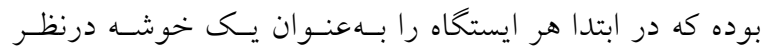

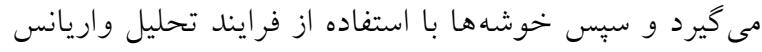

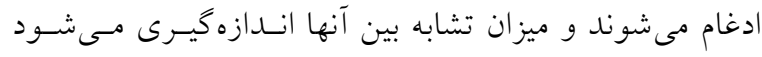

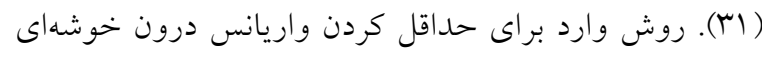


سناريوى دوم وزندهى (PCA نزديكتر است. در سناريوى سوم وزندهى (PCA

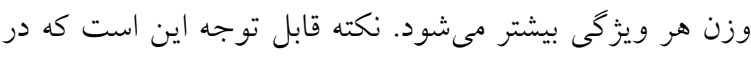

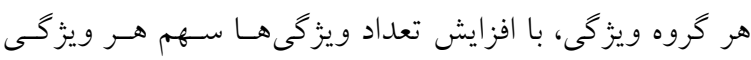

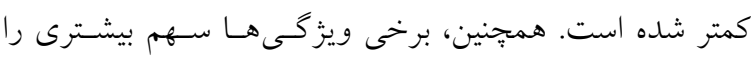

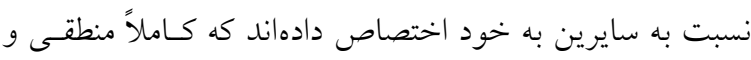

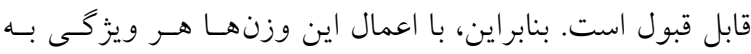
ميزان سهم خود در خوشهبندى تأثير كذار است.

\section{نتايج خوشهبندى به روش وارد}

به منظور ناحيهبندى حوضـه درياجـهـ اروميـه، ؛ـس از انتخــاب

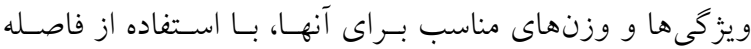

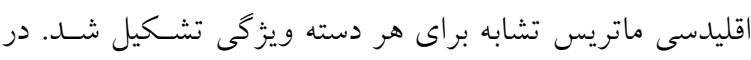

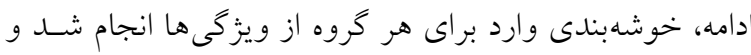
تعداد نواحى بهدست آمده در حوضه از روش خوشهبندى وارد

$$
\text { در جدول ب آورده شده است. }
$$

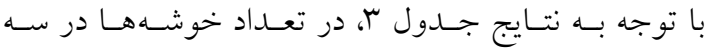
سناريوى وزندهى تغيير جندانى مشاهده نمسى شـود. در برخسى كروهها، تعداد نواحى با اعمال وزن ويزگى ها افزايش يافته و در برخى حالتهاى ديكر كاهش يافته است، درنتيجه قانون كلى را

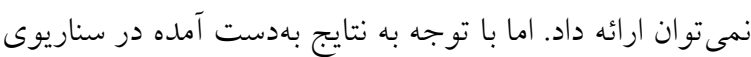

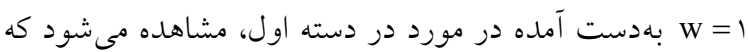

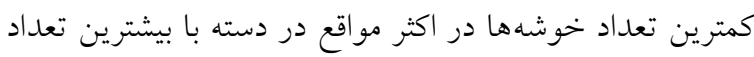

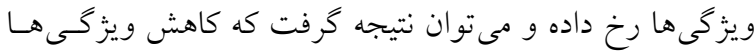

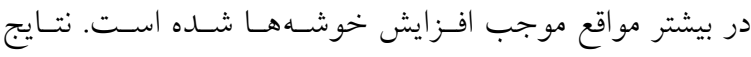
حاصل از تعداد خوشههاى بهدست آمده در سناريوى وزندهى مونى ول w = با تحقيق مدرس (9) براى بـارش حسـاكثر در كـل

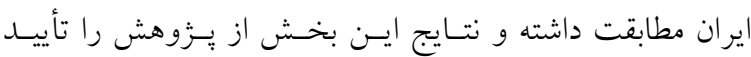

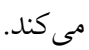

\section{نتايج معيار همخنى بر اساس وزن برابر ويزگىها}

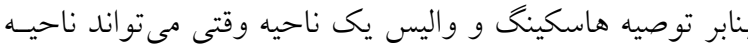

است و بهصورت رابطه (ه) و (9) تعريف مىشوند (1)): $\mathrm{H}_{\mathrm{i}}=\frac{\left(\mathrm{V}_{\mathrm{i}}-\mu_{\mathrm{V}_{\mathrm{i}}}\right)}{\sigma_{\mathrm{V}_{\mathrm{i}}}} ; \mathrm{i}=\mathrm{l}, \mathrm{r}, \mathrm{r}$

$\mathrm{V}_{\mathrm{i}}=\left\{\sum_{\mathrm{i}=1}^{\mathrm{N}} \mathrm{n}_{\mathrm{i}}\left(\tau^{(\mathrm{i})}-\tau^{\mathrm{R}}\right)^{r} / \sum_{\mathrm{i}=1}^{\mathrm{N}} \mathrm{n}_{\mathrm{i}}\right\}^{0 / \omega}$

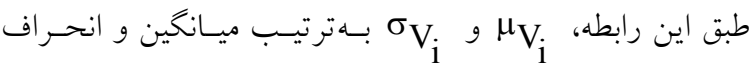
معيار مقادير شـبيهمسازى شــه Vi اسـت. در يـرّوهش حاضـر شاخص همخنى با استفاده از شبيهسازى مونت كارلو بـراى هـر

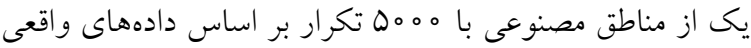
ساخته و محاسبه شد. علاوه بر اين، مقـادير ميـانخين منطقـهاى

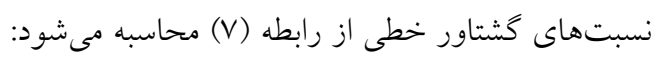
${ }_{\mathrm{t}}^{\mathrm{R}}=\frac{\sum_{\mathrm{i}=1}^{\mathrm{N}} \mathrm{n}_{\mathrm{i}} \mathrm{t}^{(\mathrm{i})}}{\sum_{\mathrm{i}=1}^{\mathrm{N}} \mathrm{n}_{\mathrm{i}}}$

كه N تعدادايستخاهها در منطقه، nول طول دوره آمارى هر ايستخاه و

نتايج و بحث نتايج روش PCA با بررسى ويزگى هاى آمارى شرايط موجود براى درصد واريانس اختصاص يافته به هر ويزگى، علاوه بر سناريوى وزندهى كه در

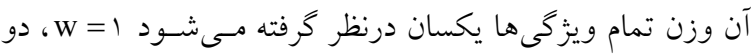
سناريوى متوسط و حداكثر مقادير ويزه هر متغيـر در مؤلفـهــاى

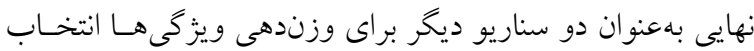

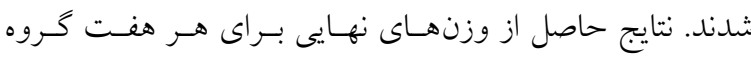
ويزگى ها در جدول ب آورده شده است.

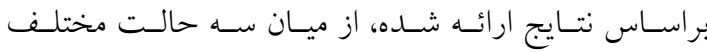
وزندهى، روش ميانخين هندسى كمترين مقدار وزن را بـهـ هـر ويزگى اختصاص داده است. همانطور كـه مشـاهده مسى شـوده،

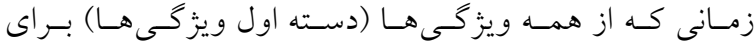
خوشهبنـدى اسـتفاده مسى شـود، وزنهـا كـاهش مسى يابنـــ. در 


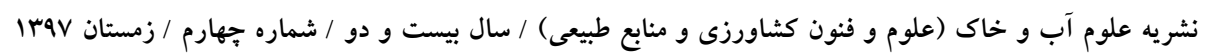

\begin{tabular}{|c|c|c|c|c|c|c|c|c|c|c|c|c|c|c|c|}
\hline \multicolumn{16}{|c|}{ جدول r. وزن هر يك از ويزگى ها در گروهها } \\
\hline \multicolumn{16}{|c|}{ All attr } \\
\hline$x$ & $<$ & $\sigma$ & $=$ & $\mathscr{2}$ & $\stackrel{5}{2}$ & $\stackrel{5}{2}$ & $\stackrel{5}{\pi}$ & $\begin{array}{l}5 \\
2 \\
3 \\
2 \\
2\end{array}$ & 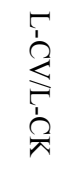 & 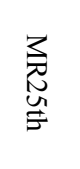 & 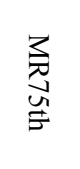 & 党 & $\begin{array}{l}\underset{\pi}{\pi} \\
\stackrel{0}{\pi} \\
\frac{\pi}{4}\end{array}$ & ఫ્ટ & \\
\hline 1 & 1 & 1 & 1 & 1 & 1 & 1 & 1 & 1 & 1 & 1 & 1 & 1 & 1 & 1 & 1 \\
\hline O/TY & $0 / Y 1$ & $0 / 49$ & $0 / 10$ & $0 / T Y$ & $0 / r$ & $0 / 19$ & $0 / 19$ & $0 / 19$ & $0 / 19$ & $\circ / 1 \Lambda$ & $0 / Y_{1}$ & $0 / I V$ & $\circ / 1 V$ & $0 / Y r$ & PCA-ave \\
\hline $0 / 4 q$ & $0 / 99$ & $0 / \& V$ & $\circ / \wedge V$ & $\circ / 0$ &.$/ 90$ & $0 / 91$ & $\circ / V \Lambda$ & $\circ / \Lambda \mid$ & $0 / 9$ & $0 / 91$ & $0 / 94$ & - /NY & $0 / 9 x^{k}$ & $\circ / N$ & PCA-max \\
\hline \multicolumn{16}{|c|}{ clim } \\
\hline & & & & & & & & & & & & 1 & 1 & 1 & 1 \\
\hline & & & & & & & & & & & & $0 / 4 q$ & $0 / \pi \Delta$ & $\circ / 4$ & PCA-ave \\
\hline & & & & & & & & & & & & $0 / 9 \mathrm{~V}$ & $0 / 99$ & $0 / 9 \mathrm{~V}$ & PCA-max \\
\hline \multicolumn{16}{|c|}{ geo } \\
\hline 1 & 1 & 1 & 1 & & & & & & & & & & & & 1 \\
\hline $0 / 41$ & $\circ / \uparrow$ & $0 / 4 q$ & $0 / 49$ & & & & & & & & & & & & PCA-ave \\
\hline $0 / 91$ & $0 / 91$ & $0 / 91$ & o/Dr & & & & & & & & & & & & PCA-max \\
\hline \multicolumn{16}{|c|}{ stat } \\
\hline & & & & 1 & 1 & 1 & 1 & 1 & 1 & 1 & 1 & & & & 1 \\
\hline & & & & $0 / \mu Y$ & $0 / T 4$ & $0 / T V$ & $0 / T V$ & $\circ / T V$ & $\circ / T V$ & $0 / Y^{K}$ & $0 / \pi 1$ & & & & PCA-ave \\
\hline & & & & $0 / Y Y$ & $0 / Y 1$ & $0 / 49$ &.$/ 10$ & $0 / Y Y$ & $0 / r$ &.$/ 19$ & $0 / 19$ & & & & PCA-max \\
\hline \multicolumn{16}{|c|}{ clim\&geo } \\
\hline 1 & 1 & 1 & 1 & & & & & & & & & 1 & 1 & 1 & 1 \\
\hline r & $0 / T_{4}$ & $0 / 7 q$ & $0 / T G$ & & & & & & & & & $\circ / T \Delta$ & $0 / T Q$ & $0 / Y \Lambda$ & PCA-ave \\
\hline .109 & $\circ / 01$ & $0 / 91$ & $0 / 9 T$ & & & & & & & & & $0 / 19$ & $0 / 91$ & $0 / 91$ & PCA-max \\
\hline \multicolumn{16}{|c|}{ clim\&stat } \\
\hline & & & & 1 & 1 & 1 & 1 & 1 & 1 & 1 & 1 & 1 & 1 & 1 & 1 \\
\hline & & & & $0 / T O$ & $0 / T 1$ & $0 / Y Y$ & $0 / Y_{0}$ & $0 / Y_{0}$ & $0 / Y 1$ & $\circ / r_{0}$ & $0 / T Y$ & $0 / 19$ & $\circ / \Lambda$ & $0 / Y 1$ & PCA-ave \\
\hline & & & & $0 / 49$ &.$/ 94$ & $\circ / V A$ & •/A &.$/ 90$ & $0 / 91$ &.$/ 9 T$ & $\circ / \Lambda t$ &.$/ 90$ & $0 / 91$ & $0 / 91$ & PCA-max \\
\hline \multicolumn{16}{|c|}{ clim\&stat } \\
\hline 1 & 1 & 1 & 1 & 1 & 1 & 1 & 1 & 1 & 1 & 1 & 1 & & & & 1 \\
\hline $0 / r \mu$ & $0 / T Y$ & $0 / Y_{0}$ &.$/ 19$ & $0 / T \Delta$ & $0 / \pi 1$ & $0 / Y_{0}$ & $0 / T_{1}$ & $0 / T r$ & $0 / Y_{0}$ & $\circ / 1 \wedge$ & س & & & & PCA-ave \\
\hline $0 / 40$ & $0 / 9 r$ & $0 / 11$ & $\circ / \Lambda 1$ & $0 / 94$ &.$/ 94$ & $0 / 99$ & $\circ / \Lambda 1$ & $\circ / 00$ & $0 / 99$ & $0 / 91$ & $\circ / \Lambda 1$ & & & & PCA-max \\
\hline
\end{tabular}

\begin{tabular}{|c|c|c|c|c|c|c|c|}
\hline جغرافيايى - آمارى & اقليمى- آمارى & |قليمى - جغرافيايى & آمارى & جغرافيايى & اقليمى & اقليم - جغرافيايى - آمارى & سناريوهاى وزندهى \\
\hline$r$ & 0 & v & 0 & 0 & $\varphi$ & $r$ & 1 \\
\hline$r$ & 0 & $r$ & $r$ & 9 & $r$ & r & PCAave \\
\hline r & r & $\varphi$ & r & 9 & 0 & r & PCAmax \\
\hline
\end{tabular}


استفاده از نخرش تحليل مؤلفهاى اصلى براى وزندهى ويزگى هاى آمارى، اقليمى ...

جدول F. مقادير H براى سناريوى وزندهى در هر گروه از ويزگىها

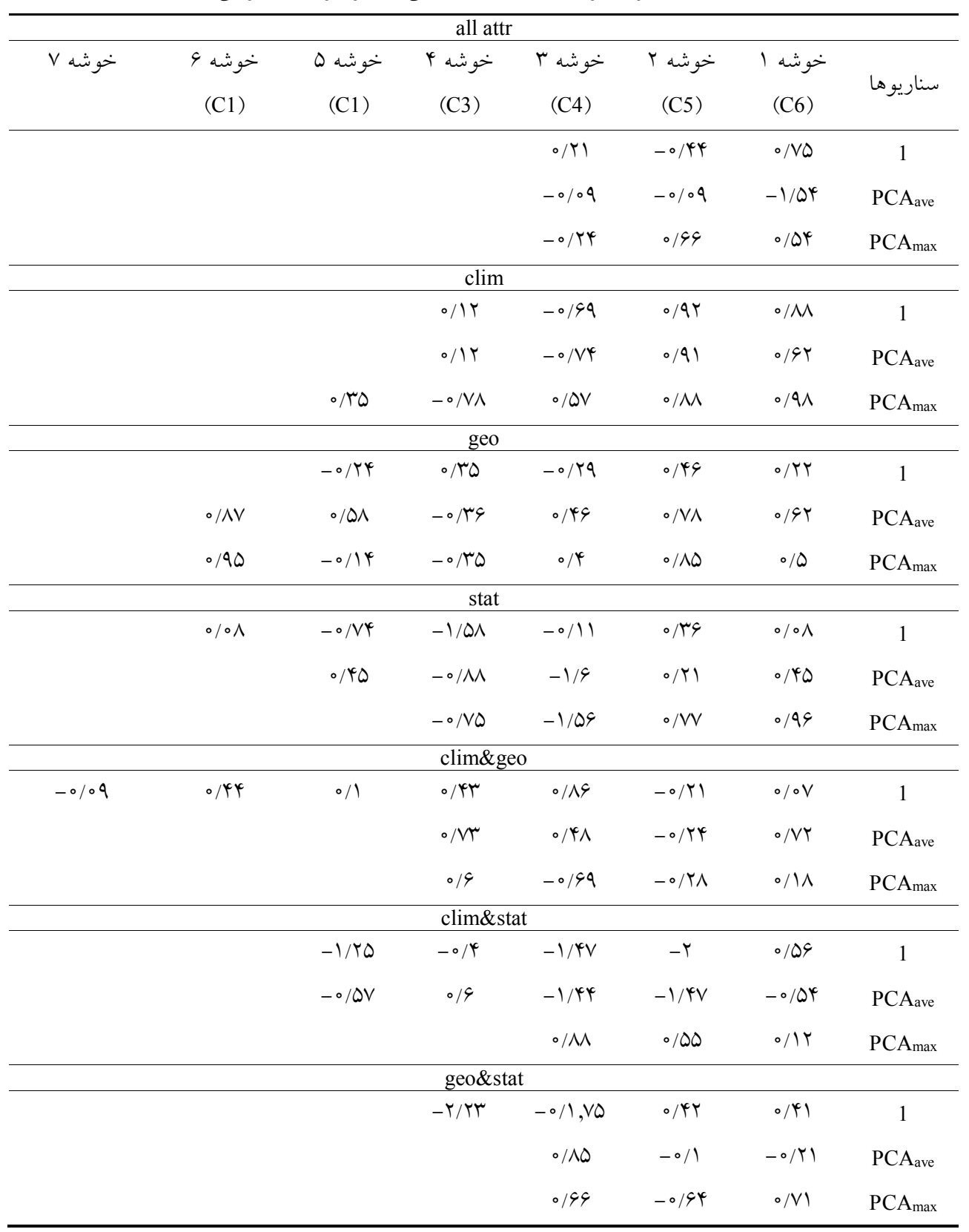

نتايج اندازه همخنى در دسـته اول كـه شـامل ويزگگىهـاى اقليمى، جغرافيايى و آمارى است و تعداد نواحى تشـكيل شــه در هر سه سناريو يكسان است، كمترين مقادير H در سـناريوى مشاهده مى شـود كـه حساكى از بهبــود همخنسى در w=PCA ave حوضه در اين دسـته اسـت. در دسـته اقليمسى نيـز نسـبت بـه سناريوى بدون وزن W=1 مشاهده مسى شـود كـه همخنسى در
همخًن قابل قبول باشد كه 1 باشد و ميىتواند ناحيـه نسـبتاً

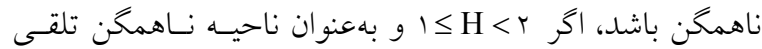

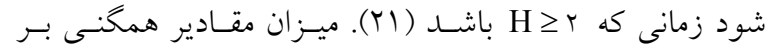
اسـاس روابـط ارائسه شــه در بخـش مـواد و روشهــا، بـراى

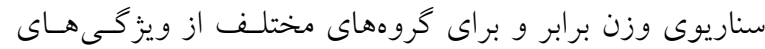
بيان شده، در جدول ثا آورده شده است. 
وجود نتايج بهتر و برآوردهايى دقيق از مقادير حدى نيست. در

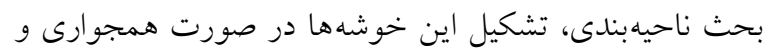

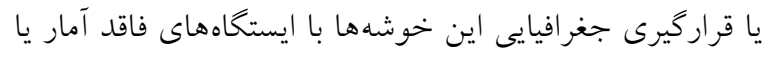

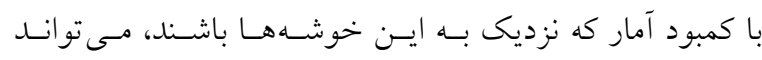

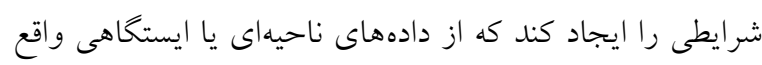

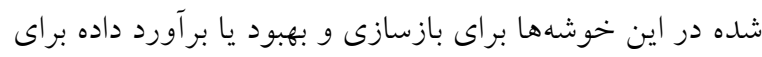

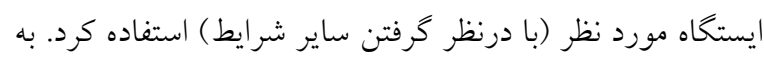

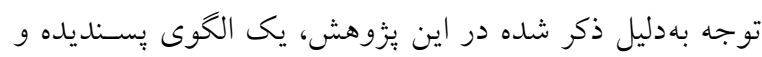

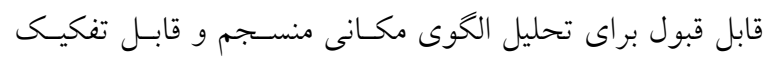
براى خوشهها در سطح حوضه ذكر شده است. خجنانجه در نتايج

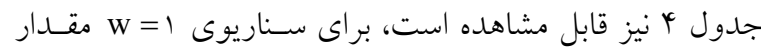

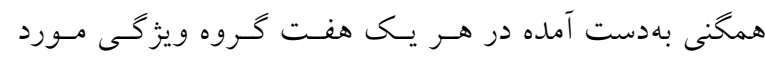

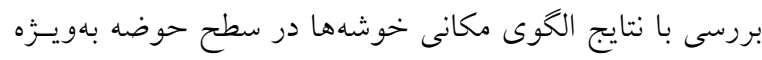

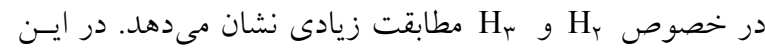

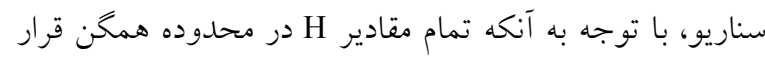

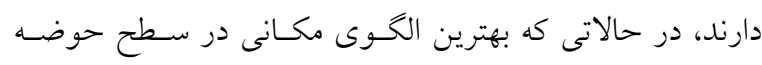

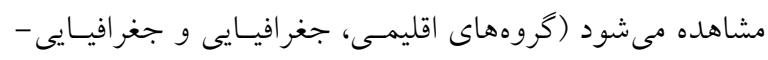

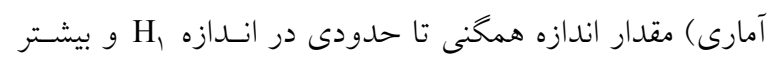

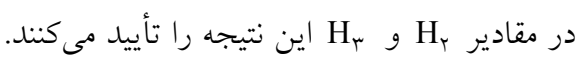

w=PCAave وزندهى ويزگ ما با بر اساس

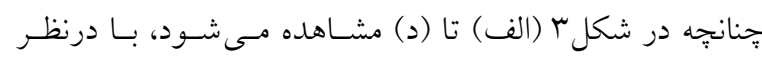

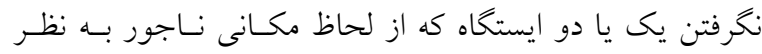

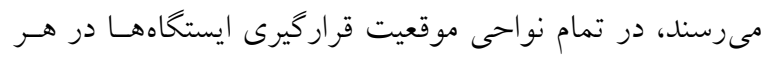

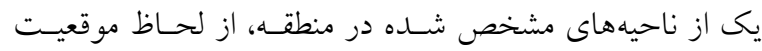

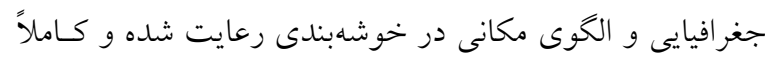

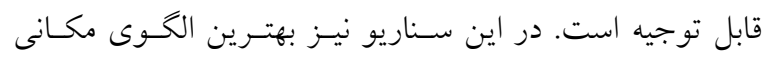

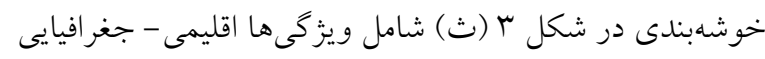

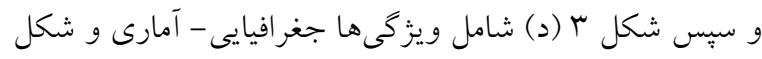

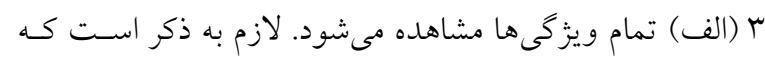

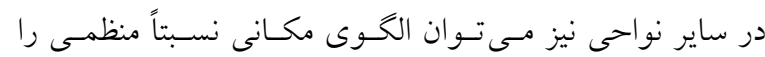

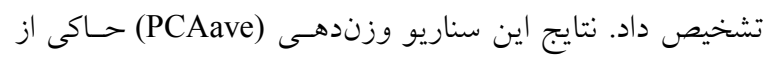

سناريوى W=PCA بهبود يافته است. بـهـطـور كلى، مسى سـوان نتيجه كرفت كه در سناريوهاى وزن داده شده مقادير H

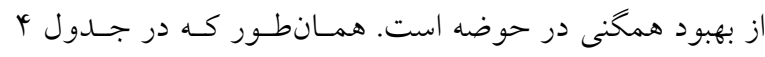

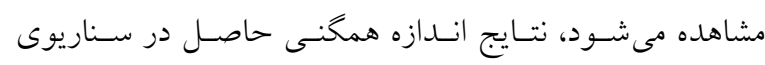

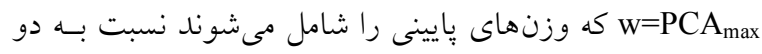

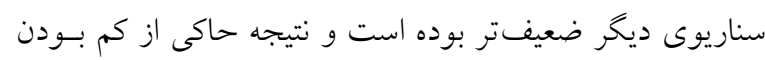
ميزان همخنى نواحى تشكيل شده نسبت به دو سـناريوى ديخـر در سطح حوضه است.

نتايج الخوى مكانى خوشهبندى حداكثر بارش MF ساعته الف) براساس سناريو

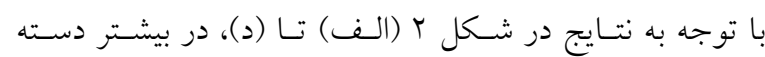

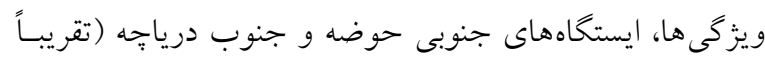
مركز حوضه) خوشههاى همخنترى را تشكيل دادهاند. همخينين

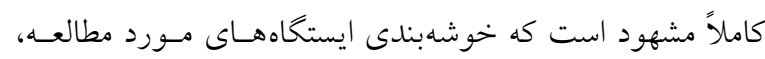

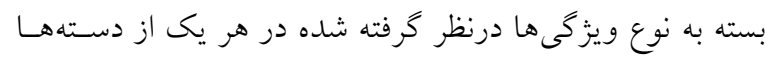

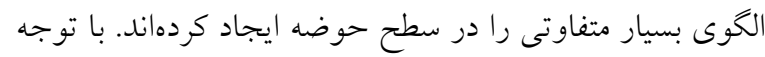

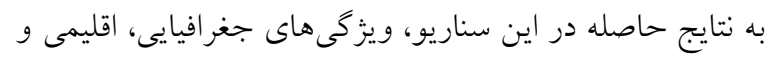

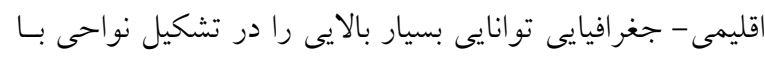
الكوى مكانى مشخص از خود نشان دادند. بهطورىكـه در ايسن

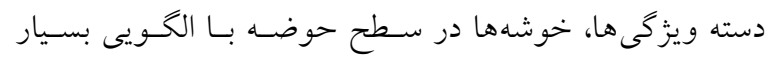

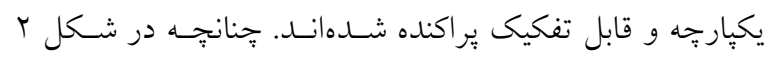

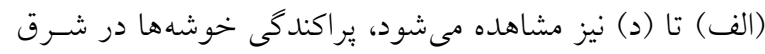

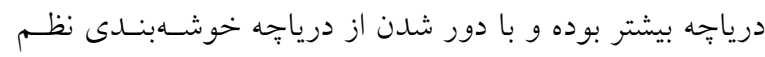

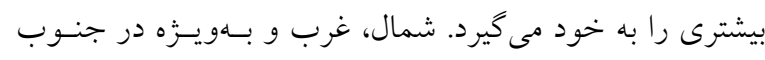

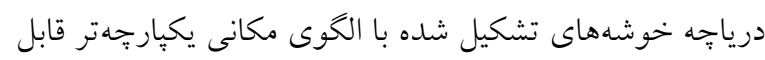

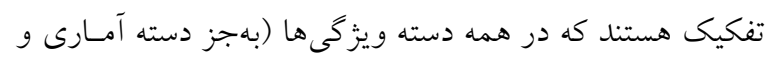

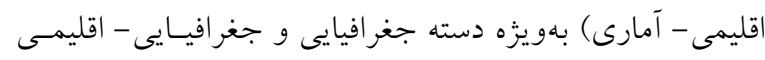
اين نتيجه مشاهده شد. علاوه بر اين، مشاهده مى شود كه بادور دور

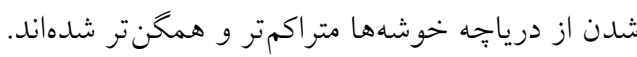

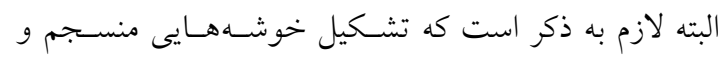

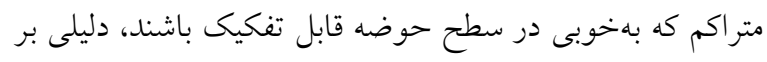



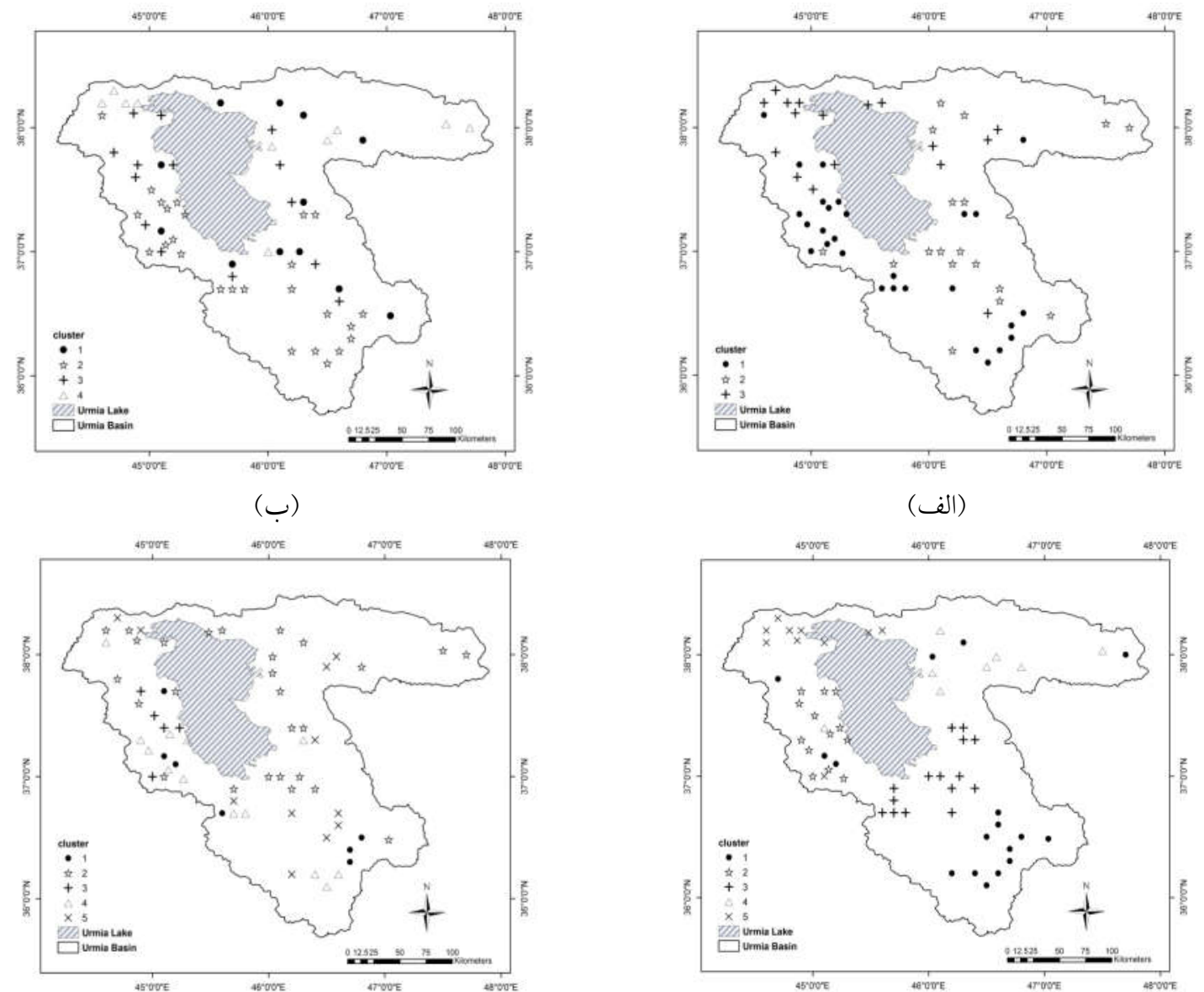

(ت)
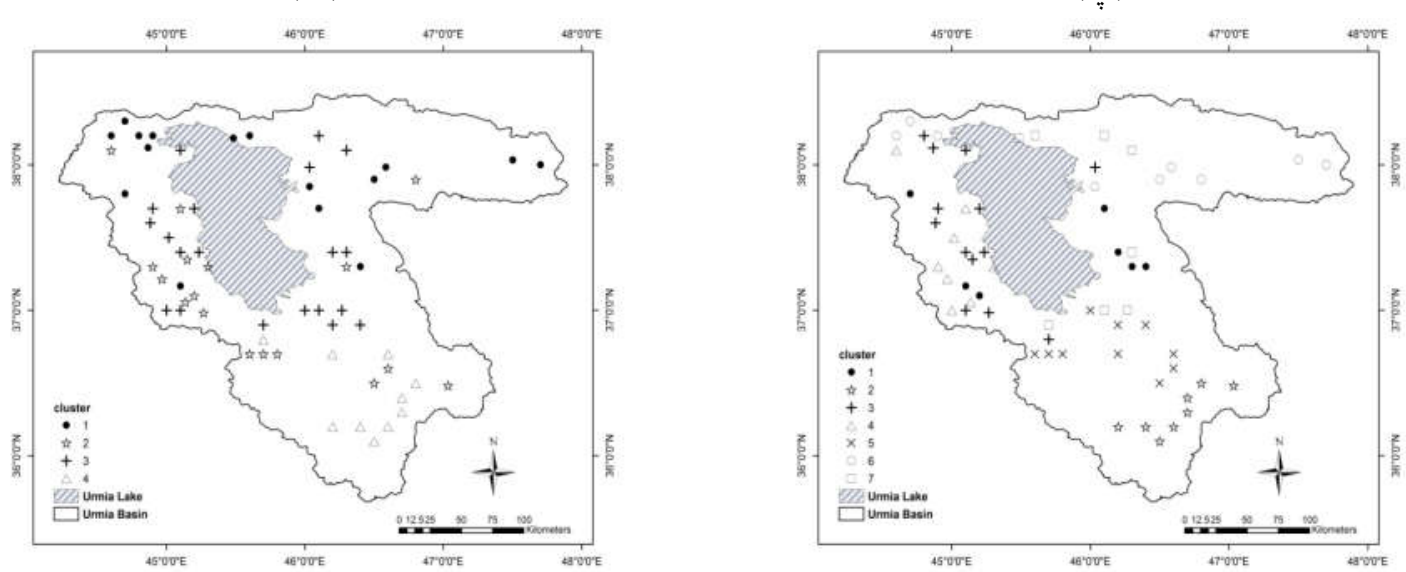

(ج)

(ث)

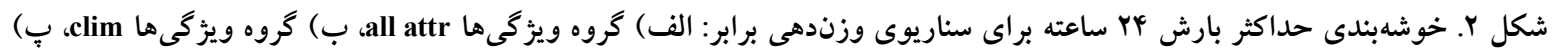

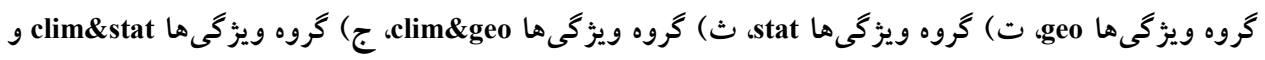
د) كروه ويزگىها 


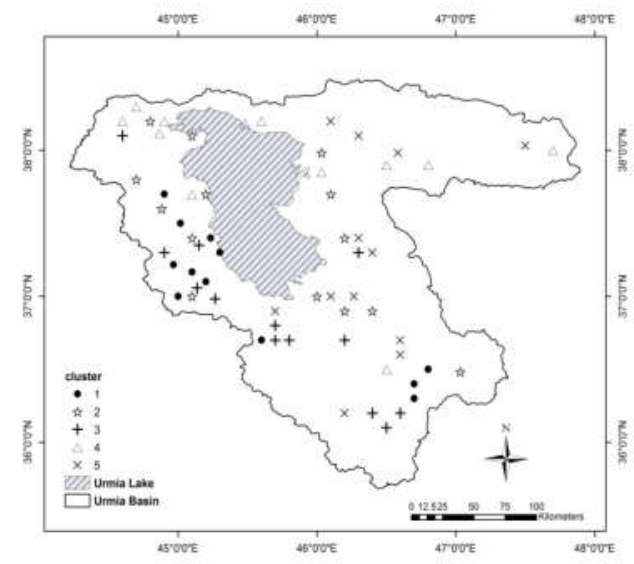

(د)

ادامه شكل r r n
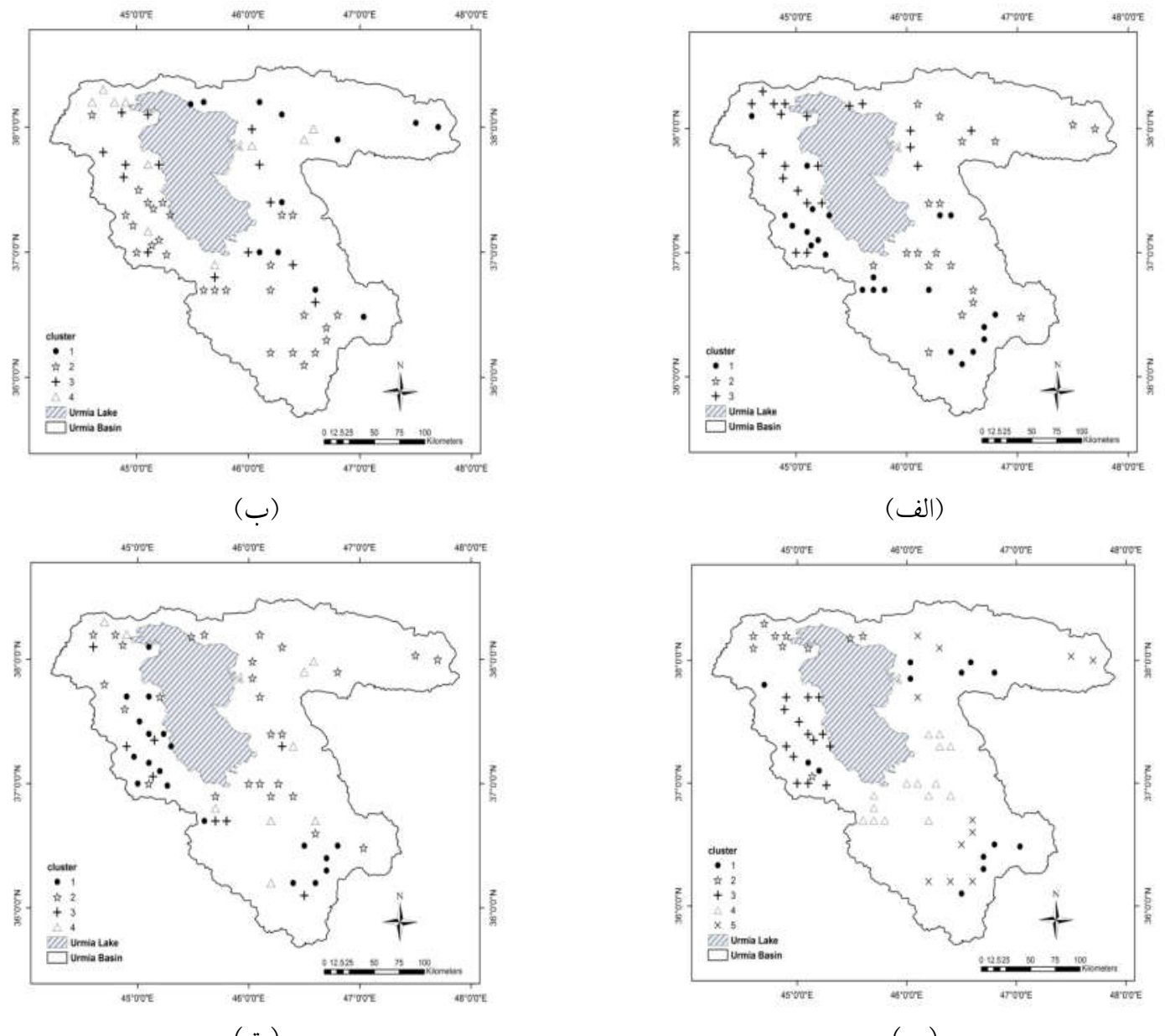

(ت)

(ب)

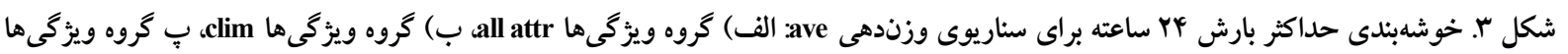

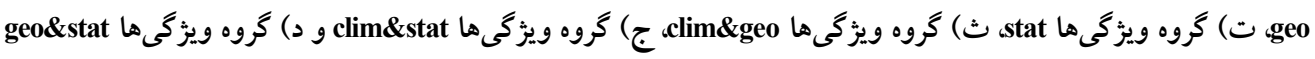



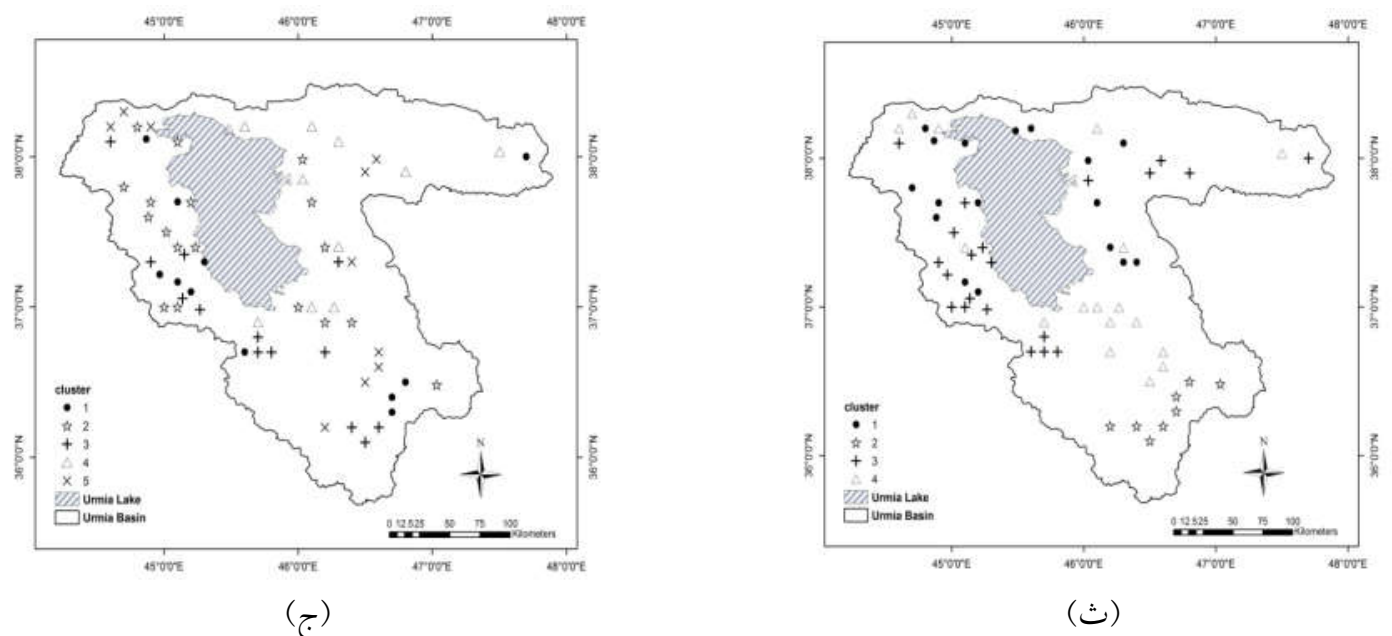

(ث)

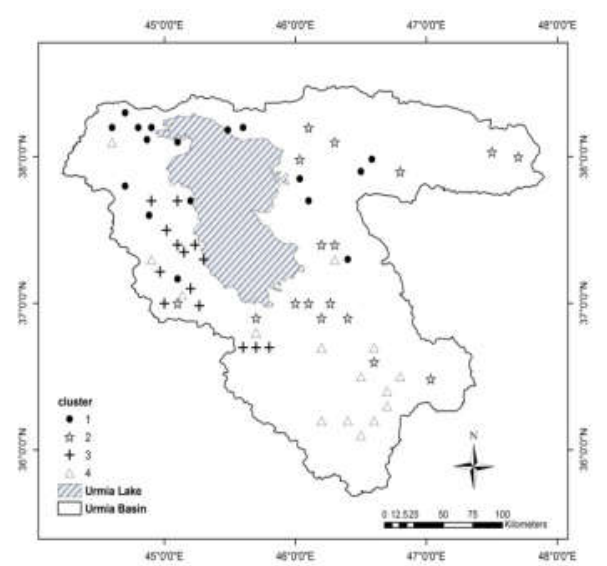

(2)

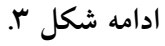

بهطوركلى مشاهده مى شود كه مقــادير H نسـبت بـه سـناريوى بدون وزن قبلى كاهش نشان داده است. اين نتيجـه بـهويـرَه در

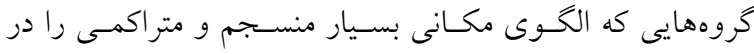
حوضه از خود نشان دادهاند (دسته اقليمى، جغرافيـيى و دستهن

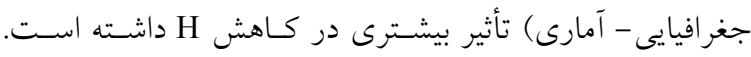
همجنين، در دسته اقليمى در اين سناريو خوشهبندى بلهويـرَّه در جنوب و غرب حوضه منسجمتر شده است.

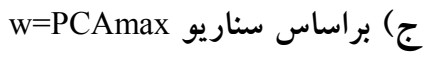

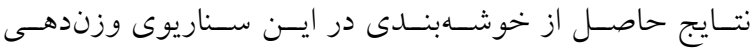

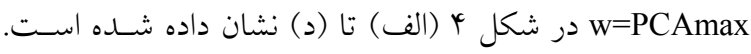

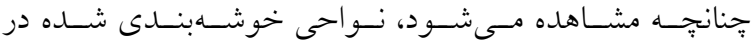

آن بود كه وزندهى ويزَكىها تا حدى توانسته است خوشسهبنـدى در

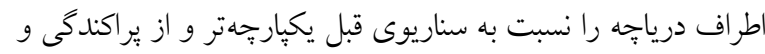

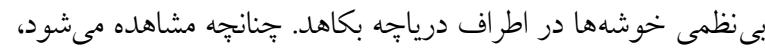
در اين سناريو درياجه خــود بـهـعــوان يـك عامـل طبيعى توانسـته

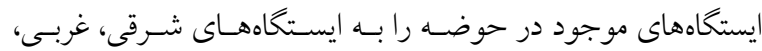

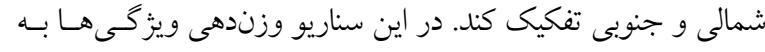

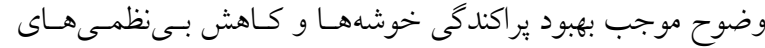

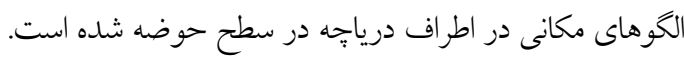

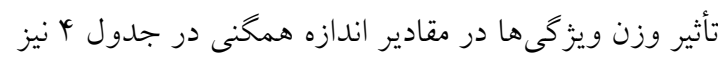

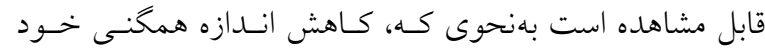

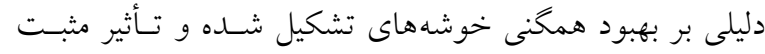

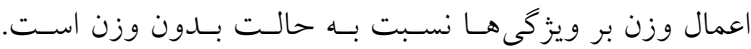


نشريه علوم آب و خاك (علوم و فنون كشاورزى و منابع طبيعى) / سال بيست و دو / شماره جهارم / زمستان VIr V
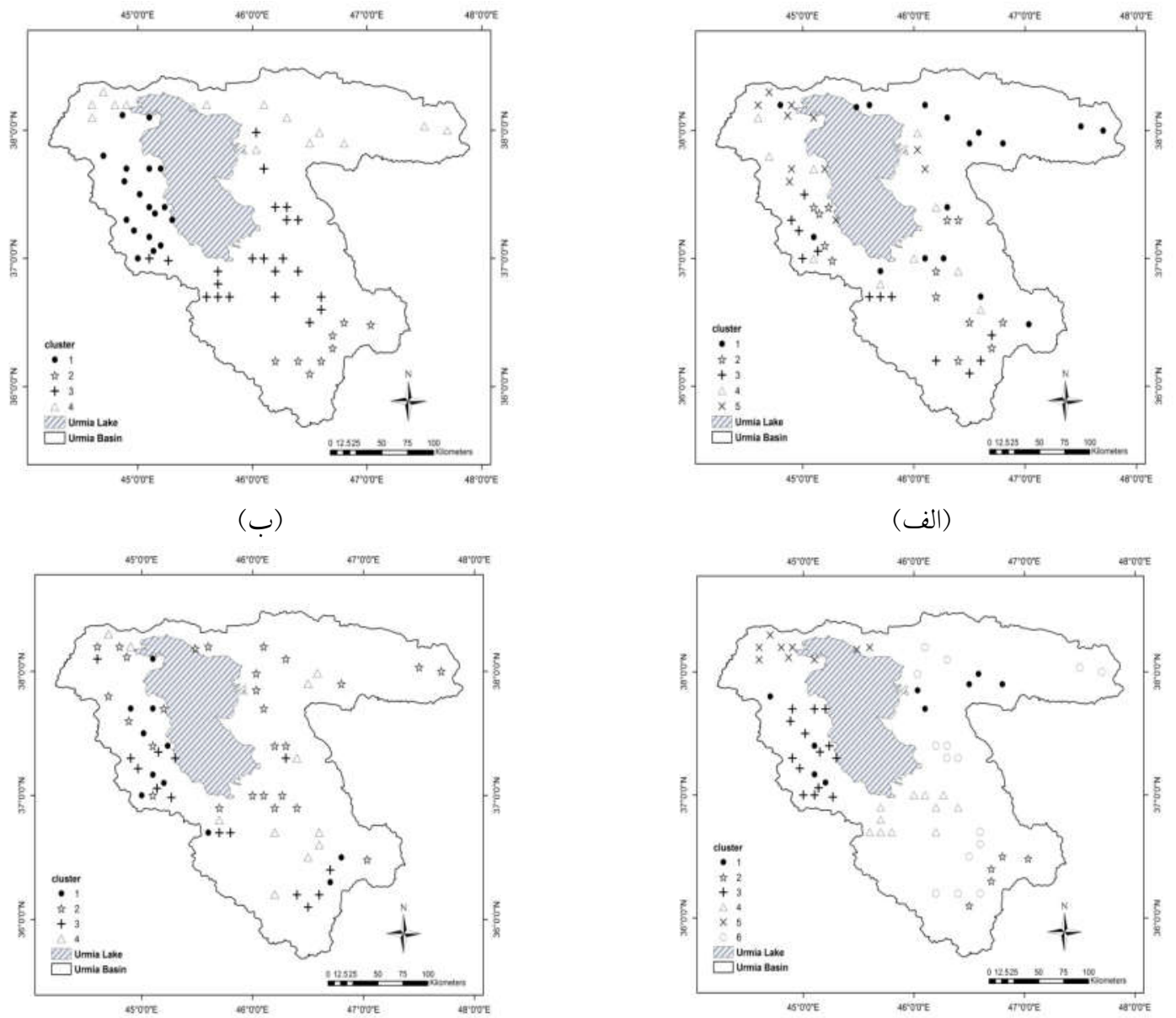

(ت)

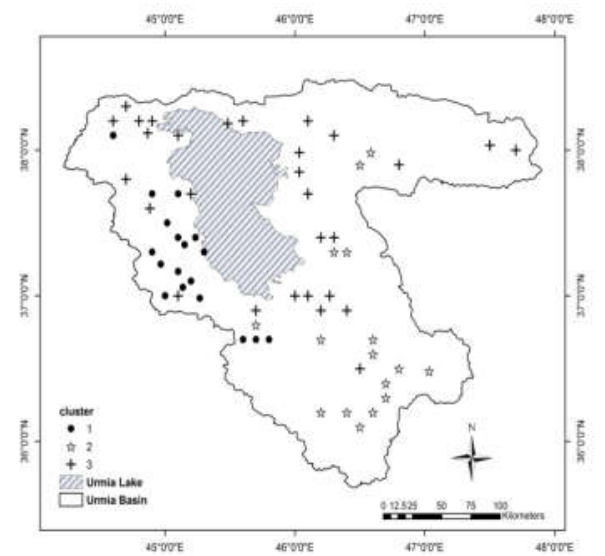

(ج)

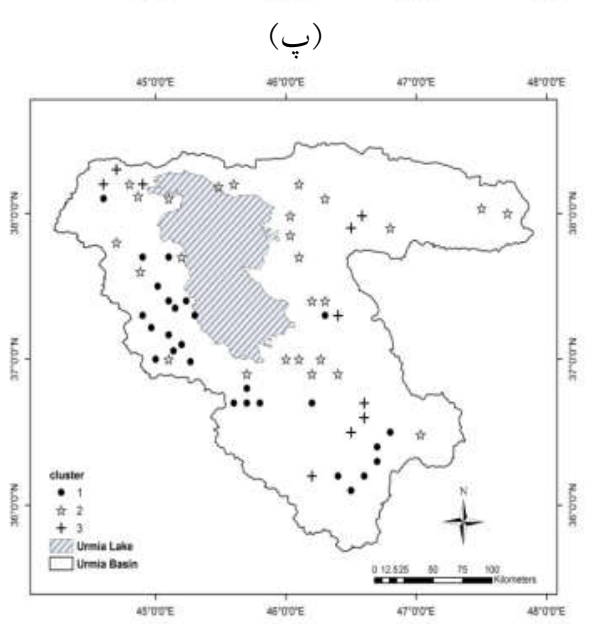

(ث)

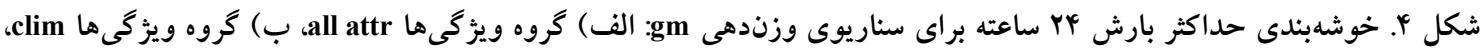

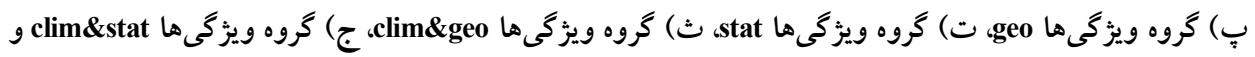

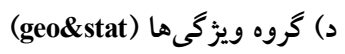




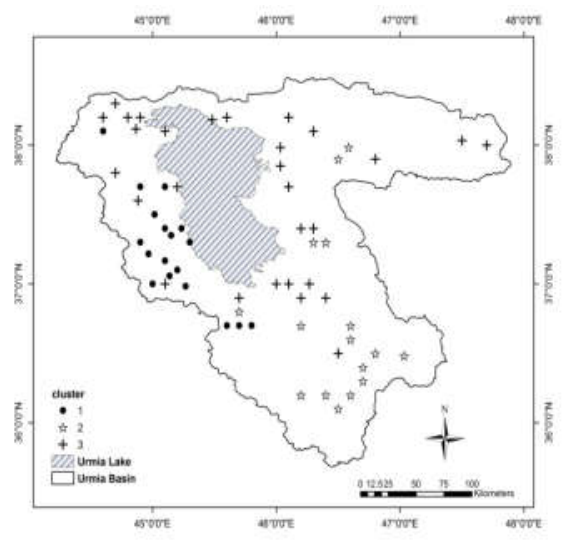

(2)

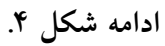

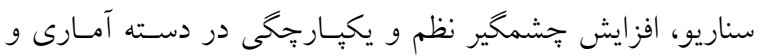

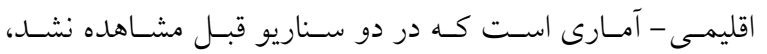

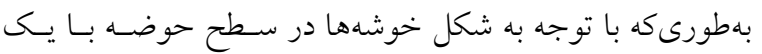

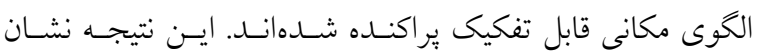

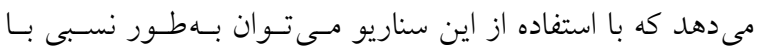

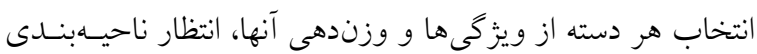
منظم و قابل قبولى را در سطح حوضه داشت. نتـايجى مشـابه بـا

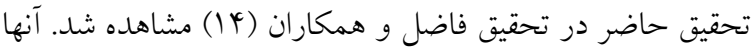

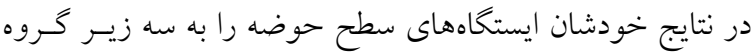
جنوبى، غربى و مركزى تقسيم كردند كه بخشى از نتـايج حاصـل از اين تحقيق را تأييد مىكند.

\section{نتيجه كيرى}

با توجه به خوشهبندى انجـام شـــه در هـر يـك از سـه دسـته

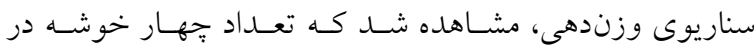
حوضه بيشترين فراوانى را در بين ساير تعداد خوشهها داراست.

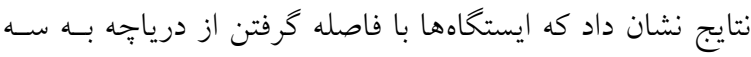

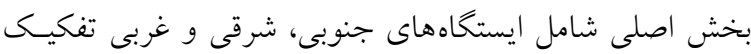

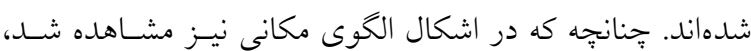

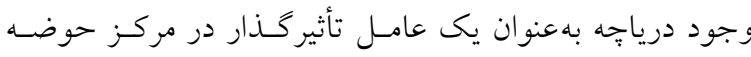
موجب شده است كه ايستخاهها در اطـراف درياجسه بـه جهـار
شكل هاى ^^ (الف)، (ب)، (ث)، (ج) و (د) الخوى مكانى بسيار

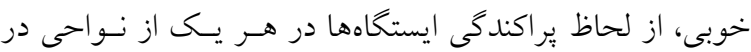

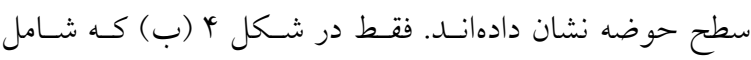

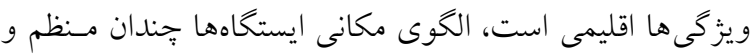

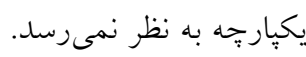

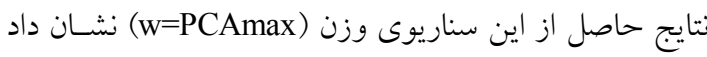

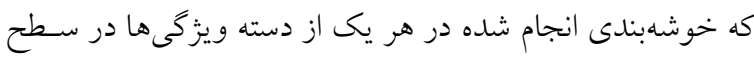
حوضه، بهصورت محسوسى منسجمتر و يكيارجهاتر از دو سناريو

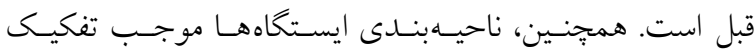

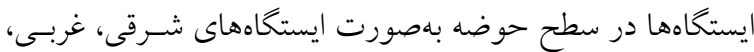

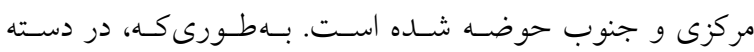

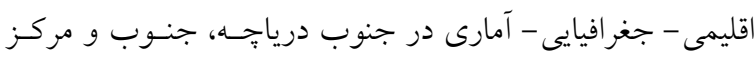

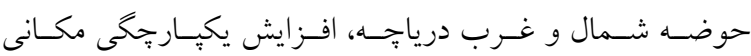
خوشههاى تشكيل شده به وضوح ديده مىشود. در دسته آمـارى

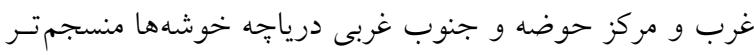
و با قدرت تفكيك بيشترى تشكيل شدهاند. بهبود و افزايش تراكم و انسجام الكوى مكانى ايستخاههاى هر خوشه در سـطح حوضسه

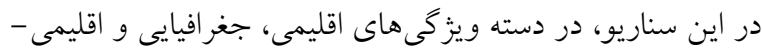
جغرافيايى كه در سناريوهاى قبل نيز مشاهده شـــه بــود، در ايسن

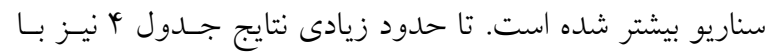

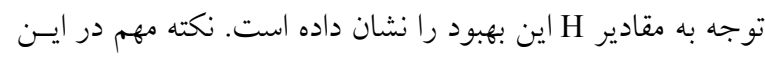


ايستخاههايى كه در يك خوشه قرار كرفتهاند، نسبت به سناريوى

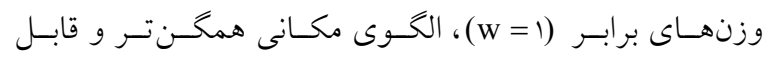

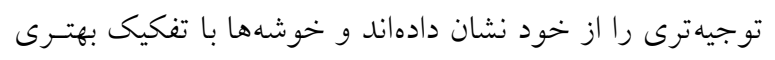

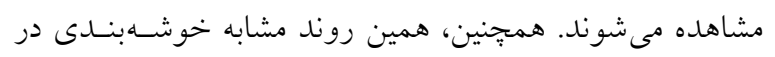

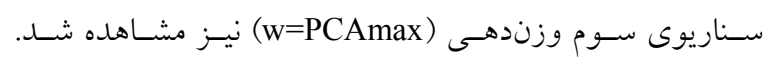

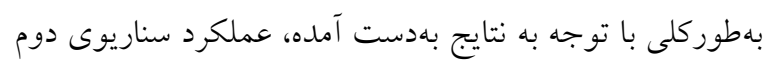
و سوم وزندهى در تفكيك حوضه از لحاظ الخوى مكانى بسيار

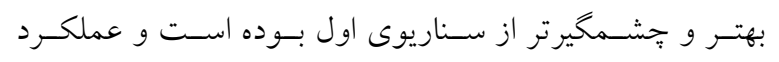

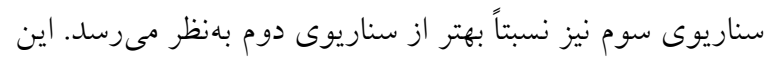

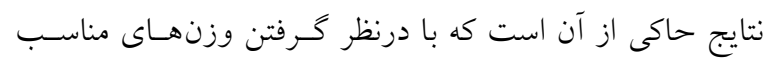

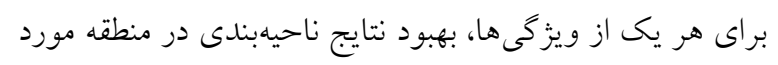

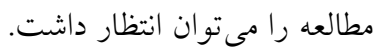

دسته ايستخاههاى شمالى، جنوبى، غربى و شـرقى تقسيمبنـدى

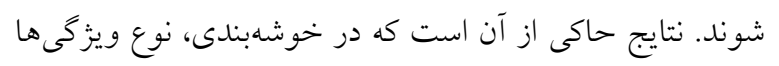

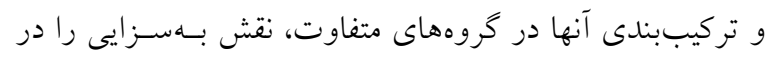

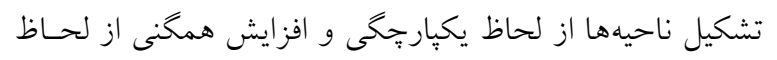

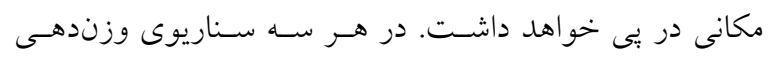

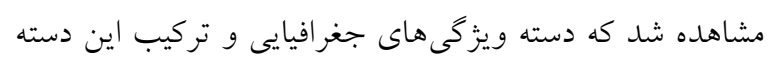

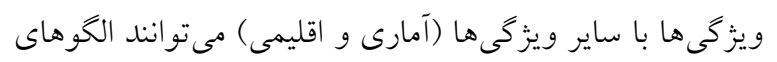

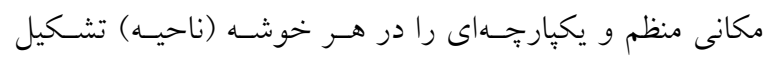

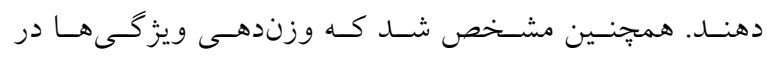

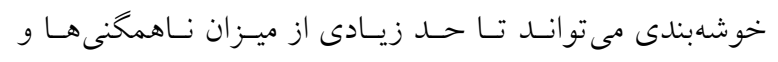

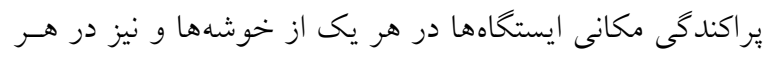

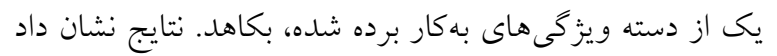
كـهـ بـــر اسـاس ســناريوى دوم وزندهــ (w=PCAave)،

\section{منابع مورد استفاده}

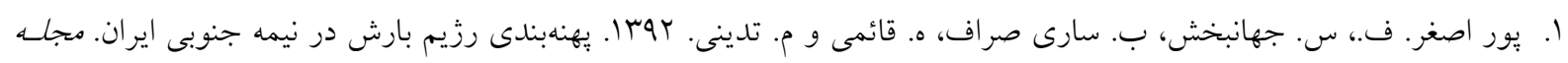

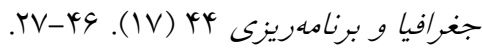

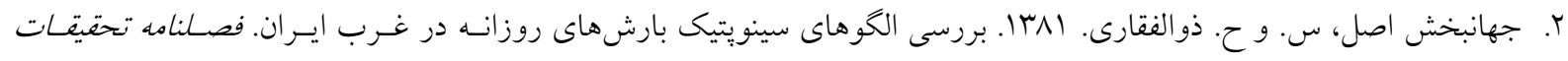

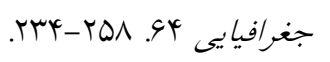

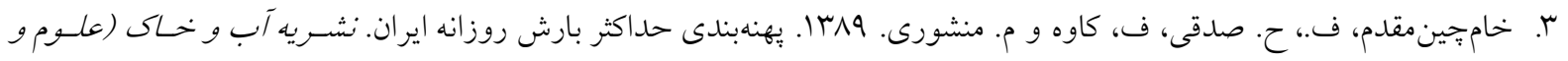

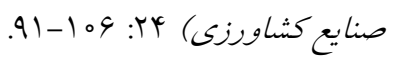

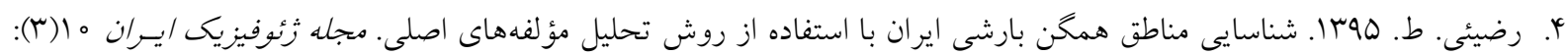

.$|Y \Lambda-| Y Y$

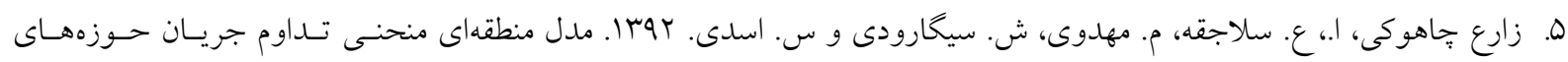

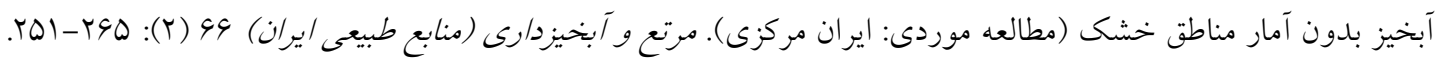

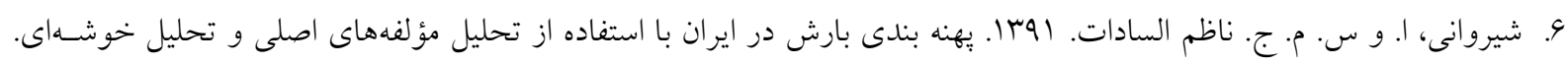

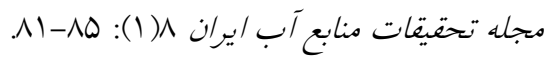

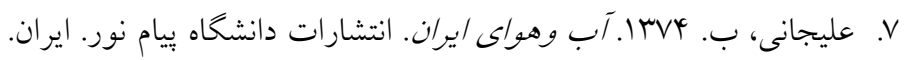

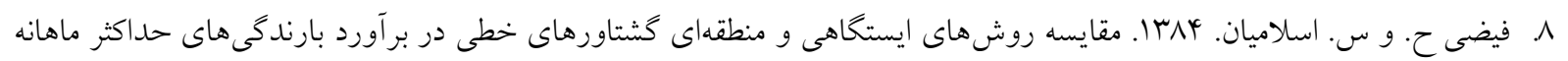

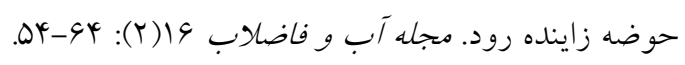

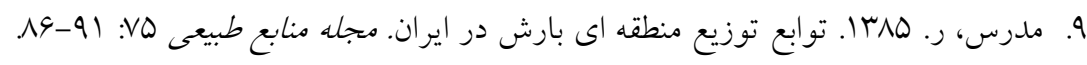

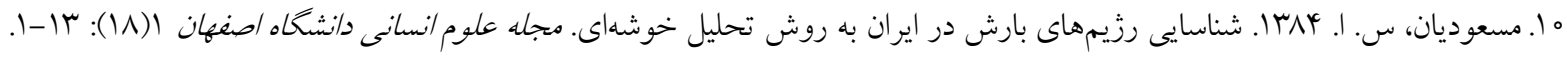


11. Bulygina N., N. McIntyre and W. Howard. 2011. Bayesian conditioning of a rainfall-runoff model for predicting flows in ungauged catchments. and under land use changes. Journal of Water Resource Research 47(2):1-13.

12. Darand M. and M. R. Mansouri Daneshvar. 2014. Regionalization of precipitation regimes in Iran using principal component analysis and hierarchical clustering analysis. Journal of Environmental Processess 1: 517-532.

13. Dinpashoh, Y., A. Fakheri-Fard, M. Moghaddam, S. Jahanbakhsh and M. Mirnia. 2004. Selection of variables for the purpose of regionalization of Iran's precipitation climate using multivariate methods. Journal of Hydrology 297: $109-123$

14. Fazel, N., R. Berndtsson, C. Bertacchi Uvo, K. Madani and B. Kløve. 2017. Regionalization of precipitation characteristics in Iran's lake urmia basin. Theoretical Applied Climatology Journal 132(1-2): 363-373.

15. Heuvelmans, G., B. Muys and J. Feyen, 2006. Regionalization of the parameters of a hydrological model. Comparison of linear regression models with artificial neural nets. Journal of Hydrology 319(1-4): $245-265$.

16. Hosking, J. R. M. and J. R. Wallis. 1997. Regional frequency analysis: an approach based on L-moments, Cambridge University, England.

17. Hosking, J. R. and J. R. Wallis. 1991. Some Statistics Useful in Regional Frequency Analysis. Res. Rep. RC 17096, IBM Research Division, Yorktown Heights, New York.

18. Hotelling H. H. 1933. Analysis of complex statistical variables into principal components. Journal of Educational Psychology 24: 417-520

19. Hutcheson, G. and S. Nick. 1999. The Multivariate Social Scientist: Introductory Statistics Using Generalized Linear Models, Sage Publications, Thousand Oaks, CA.

20. Jiang, Y., H. Guoa, Y. Jia, Y. Cao and C. Hu. 2014. Principal component analysis and hierarchical cluster analyses of arsenic groundwater geochemistry in the Hetao basin, Inner Mongolia. Journal of Chemie der Erde-Geochemistry 75(2):197-205.

21. Jollife, I. T. 2002. Principal Component Analysis. Part $2^{\text {nd }}$ ed. Springer, Verlag, New York.

22. Johnson, R. A. and D. W. Wichern. 1982. Applied Multivariate Statistical Analysis, $3^{\text {rd }}$ Ed, Prentice-Hall Inc., Englewood Cliffs, SA.

23. Lima, C. H. R. and U. Lall. 2010. Spatial scaling in a changing climate. A hierarchical Bayesian model for nonstationary multi-site annual maximum and monthly streamflow. Journal of Hydrology 383(3-4): 307-318.

24. Merz, B. and G. Bloeschl 2004. Regionalization of catchment model parameters. Journal of Hydrology 287: 95-123.

25. Modarres, R. and A. Sarhadi. 2011. Statistically-based regionalization of rainfall climates of Iran. Global and Planetary Change 75: 67-75.

26. Olden, J. D., M. J. Kennard and B. J. Pusey. 2012. A framework for hydrologic classification with a review of methodologies and applications in ecohydrology. Journal of Ecohydrology 5:503-518.

27. Post, D. A. 2009. Regionalizing rainfall-runoff model parameters to predict the daily streamflow of ungauged catchments in the dry tropics. Journal of Hydrology Research 40(5): 433-444.

28. Razavi, T. and P. Coulibaly. 2013. Classification of Ontario watersheds based on physical attributes and streamflow series. Journal of Hydrology 493: 81-94.

29. Samaniego, L., A. Bardossy and R. Kumar. 2010. Streamflow prediction in ungauged catchments using copulabased dissimilarity measures. Journal of Water Resource Research 46(2): 1-22.

30. Samuel, J., P. Coulibaly and R. A. Metcalfe 2011. Estimation of continuous streamflow in Ontario ungauged basins. Comparison of regionalization methods. Journal of Hydrology Engineering 16(5):447-459.

31. Ward, J. and H. Joe. 1963. Hierarchical grouping to optimize an objective function. Journal of the American Statistical Association 58(301): 236-244.

32. Wazneh, H., F. Chebana and T. B. M. J. Ouarda. 2013. Depth-based regional index-flood model. Journal of Water Resources Research 49(12): 7957-7972.

33. Zhang Z., T. Wagener, P. Reed and R. Bhushan. 2008. Reducing uncertainty in predictions in ungauged basins by combining hydrologic indices regionalization and multiobjective optimization. Journal of Water Resource Reserch 44(12). 


\title{
Using the Principal Component Analysis Approach for Weighting Statistical, Climatic and Geographical Attributes of the Maximum 24-hour Rainfall and Spatial Clustering Analysis (A Case Study: Urmia Lake Basin)
}

\author{
Z. Dehghan ${ }^{1 *}$, S. S. Eslamian ${ }^{1}$ and R. Modarres $^{2}$
}

(Received: March 4-2017; Accepted: October 22-2017)

\begin{abstract}
Regionalization is one of the useful tools for carrying out effective analyses in regions lacking data or with having only incomplete data. One of the regionalization methods widely used in the hydrological studies is the clustering approach. Moreover, another effective factor on clustering is the degree of importance and participation level for each of these attributes. In this study, it was tried to use a broad range of attributes to compare their performance in regionalization. Then, according to the importance and role of each attribute in regionalization, the appropriate weight for each of the attributes in each category was determined using the principal component analysis (PCA) method, and the effect of this weighting in forming the homogenous regions was investigated by the Ward's clustering method. In this regard, the maximum 24-hour rainfall data of 63 meteorological stations located in Urmia Lake Basin (ULB) was used in this study during a time period of 30 years (1979-2008). Furthermore, seven categories of attributes were defined in order to regionalize the rainfall. The results showed that by considering different attributes and combining them with each other, a different clustering is obtained in each category in terms of the number of clusters and stations. Among seven categories of attributes, it was found that the geographical and climatic-geographical categories of attributes showed a more appropriate clustering over the ULB. Additionally, the weighting of attributes could have more effect on improving homogeneity and forming the independent clusters in most cases in terms of the scattering of station and how to locate over the basin.
\end{abstract}

Keywords: Principle component analysis, Urmia Lake basin, Ward's clustering method, Attributes' weighting

1. Department of Water Engineering, Faculty of Agriculture, Isfahan University of Technology, Isfahan, Iran.

2. Department of Rangeland and Watershed Management, College of Natural Resources, Isfahan University of Technology, Isfahan, Iran.

*: Corresponding Author, Email: z.dehghan@ag.iut.ac.ir 